\title{
WestVirginiaUniversity
}

THE RESEARCH REPOSITORY @ WVU

Graduate Theses, Dissertations, and Problem Reports

2003

\section{Essays on international political economy}

Tomi Ovaska

West Virginia University

Follow this and additional works at: https://researchrepository.wvu.edu/etd

\section{Recommended Citation}

Ovaska, Tomi, "Essays on international political economy" (2003). Graduate Theses, Dissertations, and Problem Reports. 1885.

https://researchrepository.wvu.edu/etd/1885

This Dissertation is protected by copyright and/or related rights. It has been brought to you by the The Research Repository @ WVU with permission from the rights-holder(s). You are free to use this Dissertation in any way that is permitted by the copyright and related rights legislation that applies to your use. For other uses you must obtain permission from the rights-holder(s) directly, unless additional rights are indicated by a Creative Commons license in the record and/ or on the work itself. This Dissertation has been accepted for inclusion in WVU Graduate Theses, Dissertations, and Problem Reports collection by an authorized administrator of The Research Repository @ WVU.

For more information, please contact researchrepository@mail.wvu.edu. 


\title{
Essays on International Political Economy
}

\author{
Tomi Ovaska \\ Dissertation submitted to the \\ College of Business and Economics \\ at West Virginia University \\ in partial fulfillment of the requirements for the degree of \\ Doctor of Philosophy \\ in \\ Economics \\ Russell S. Sobel, Ph.D., Chair \\ Ronald J. Balvers, Ph.D. \\ Stratford M. Douglas, Ph.D. \\ George W. Hammond, Ph.D. \\ William N. Trumbull, Ph.D. \\ Morgantown, West Virginia \\ 2003
}

Keywords: Government growth, fiscal illusion, development aid, aid effectiveness, economic growth, entrepreneurship, transition economies.

Copyright (C) 2003 Tomi Ovaska 


\section{ABSTRACT \\ Essays on International Political Economy}

Tomi Ovaska

This dissertation is a collection of essays that focus on the effects of government intervention on economic outcomes. The work is empirical in nature and incorporates cross-country comparisons to highlight the effect governments potentially have in influencing the working of markets. The essays in this dissertation ask what governments actually do and why, what governments should avoid doing, and finally, what governments should undertake to foster economic progress. Chapter one is a short introduction to the role governments play in modern societies. Chapter two considers what governments do and why, focusing on fiscal illusion. Contrary to the fiscal illusion hypothesis, this study finds that an increase in the share of indirect taxes actually decreases the size of government as a share of GDP. It is hypothesized that this result could stem from politicians' desire to design such tax structures that minimize the political resistance for tax increases. As with fiscal illusion, there is no guarantee that this outcome would be optimal in terms of excess burden of taxation. Chapter three analyzes the effectiveness of international development aid. The results of this chapter indicate that development aid does not seem to improve economic growth. It is hypothesized that this result may emanate, among other things, from the harmful incentive aid imposes upon work effort, and from tied aid that may lead to misallocation of recipient countries' scarce resources. Chapter four concentrates on governments' role in post-socialist economies in fostering entrepreneurial activity, looking at the policies and institutions that appear to be the most highly correlated with a country's success (or failure) in promoting entrepreneurial activity. The results of this essay indicate that to be successful, the presence of enabling environment, i.e., economic freedom and "good" policies - such as low taxes, low regulations, and secure private property rights - is of crucial importance. Chapter five provides a summary of the results of the dissertation and discusses potential directions of future research investigating fiscal illusion, international development aid and entrepreneurship in transition economies. 


\section{ACKNOWLEDGEMENTS}

I am greatly indebted to my wife Rachel for her inestimable help, support and understanding during my four years in graduate school. Accommodating my schedule while taking care of our three children - Henriette, Jacob and Theodore - and everything that goes together with being a family was no doubt tough at times, yet she managed everything with flying colors. A great achievement which I hope to be able to repay in the years to come. I would also like to thank my excellent and enthusiastic dissertation chair Dr. Russell Sobel, in particular, and the other committee members, Drs Ronald Balvers, Stratford Douglas, George Hammond and William Trumbull, for their knowledgeable advice and suggestions that greatly improved the quality of the dissertation. My closest co-workers and fellow graduate students in the program, Aziz Saglam, Matthew McPherson and Ryo Takashima also most certainly deserve great credit for my graduation. Not only have they been great friends and helpers during my years in Morgantown, but they are also great economists from whom we will hear more from in the future, I am sure. Finally, it is time to thank the WVU's Ph.D. economics program in general, and all the people behind it. The program may not have taught me everything there is to know about economics, but it certainly provides the tools that enable young economists to go to the world, acquire new knowledge, and prosper on their own. Actually, that is no small feat. 


\section{LIST OF TABLES}

Table 2.1. - Variable explanations and expected signs ................................................... 23

Table 2.2. - Estimates of the combined 1988 and 1993 expenditure equations .................. 25

Table 3.1. - Estimates of the 1975-1998 real GDP growth per capita equations ............... 45

Table 4.1. - Selected economic and entrepreneurship data for the transition economies .... 55

Table 4.2. - Estimates of the 1995-2000 new enterprise creation equations ...................... 60

Table 4.3. - Estimates of the 1995-2000 patent and trademark applications equations ...... 61

Table A.1. - Fiscal illusion: List of countries ................................................................. 81

Table A.2. - Fiscal illusion: Descriptive statistics ..................................................... 82

Table A.3. - Fiscal illusion: Variable explanations and data sources .............................. 83

Table A.4. - Fiscal illusion: Composition of fiscal illusion variables.............................. 85

Table B.1. - Development aid: List of countries ........................................................... 86

Table B.2. - Development aid: Descriptive statistics .............................................. 87

Table B.3. - Development aid: Variable explanations and data sources ........................... 88

Table C.1. - Entrepreneurship: List of countries ................................................. 90

Table C.2. - Entrepreneurship: Descriptive statistics ................................................... 91

Table C.3. - Entrepreneurship: Variable explanations and data sources .......................... 92 


\section{TABLE OF CONTENTS}

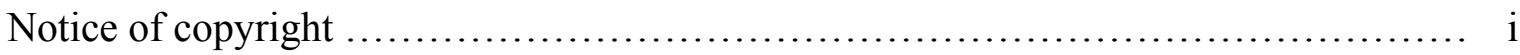

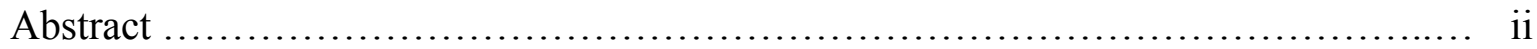

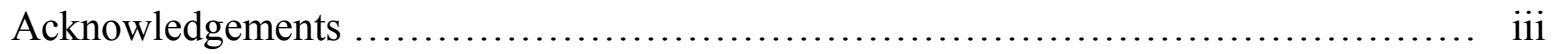

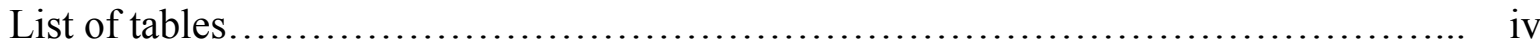

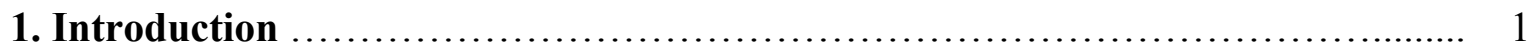

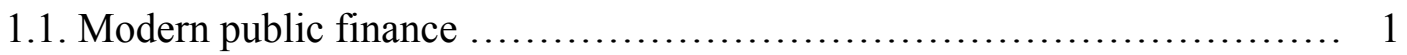

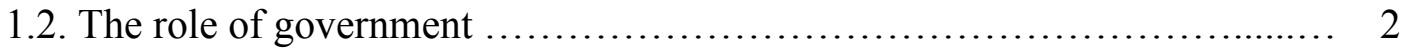

1.3. Two views on the efficiency of political system ....................... 4

1.4. The three essays ............................................... 7

2. Government Growth and Fiscal Illusion: New International Evidence ......... 8

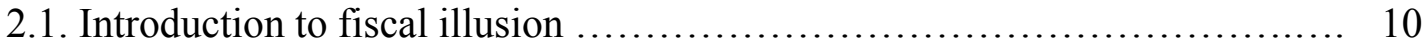

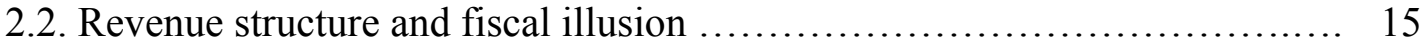

2.3. Methodological considerations .................................... 16

2.4. Government size, tax structure and economic growth ................... 19

2.5. The model and empirical results ................................. 20

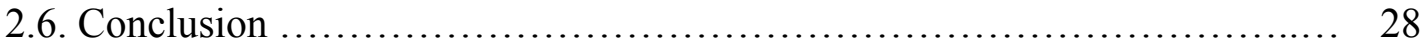

3. The Effectiveness of International Development Aid ...................... 31

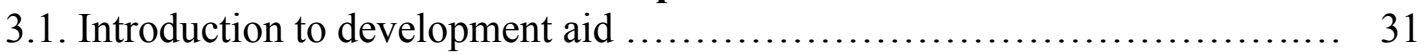

3.2. Theories explaining aid-ineffectiveness ............................. 32

3.3. Previous literature .................................................... 38

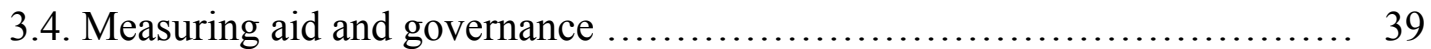

3.5. The model and empirical results .................................. 41

3.6. Conclusion ...................................................... 48

4. Entrepreneurship in Post-Socialist Economies ............................. 51

4.1. Introduction to entrepreneurship in transition economies ................... 51

4.2. Transitional success and entrepreneurship ........................... 54

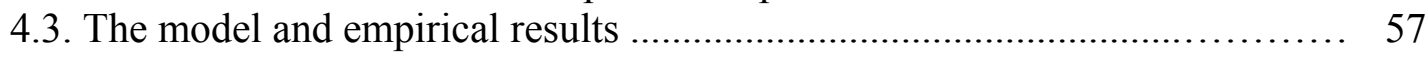

4.4. Conclusion .................................................... 65

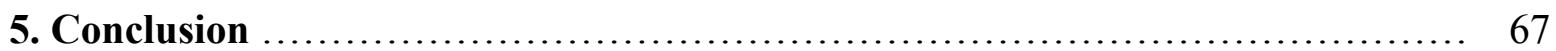

5.1. Government growth and fiscal illusion: New international evidence ........ 67

5.2. The effectiveness of international development aid .................... 71

5.3. Entrepreneurship in post-socialist economies ........................ 74

5.4. Government and the economy ..................................... 79 
Appendix A - Government growth and fiscal illusion $\ldots \ldots \ldots \ldots \ldots \ldots \ldots \ldots \ldots \ldots \ldots . \ldots 1$

Appendix B - The effectiveness of international development aid................. 86

Appendix C - Entrepreneurship in post-socialist economies $\ldots \ldots \ldots \ldots \ldots \ldots \ldots \ldots \ldots \ldots .90$

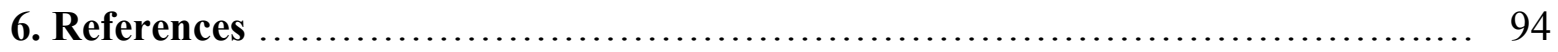




\section{INTRODUCTION}

This dissertation is a collection of three essays that focus on the effects of government intervention on economic outcomes. The work is empirical in nature and incorporates crosscountry comparisons in highlighting the effect governments potentially have in influencing the working of markets.

\subsection{Modern public finance}

The field of public finance has traditionally kept its center of attention on issues like taxation and spending. In the last decades, though, the field has greatly expanded by including in its analysis the interaction between economics and politics. This resurrection of political economy has brought to the forefront the idea that the creation and results of any new economic policy are influenced by the surrounding political system. This interaction of economics and politics can be, but is not necessarily, beneficial to society.

Self-interest is a powerful factor in human behavior. Not only does it motivate people to work to improve their own lot, but at the same time people's attempt to further their own interest has been shown to benefit the society as well. The situation changes somewhat, though, when we consider the case of people who work for the government. Self-interest may no longer align with the larger goals, i.e., the public interest, society promotes. As Wicksell (1896), Bowen (1943), Black (1948), Arrow (1951), Downs (1957), and Buchanan \& Tullock

(1962), among others, have shown, the situation is further complicated by the fact that the concept of public interest is both highly elusive and also hard if not impossible to attain due to imperfections in every known voting system,. 
Modern political economy centers around the question of how to set up governments to achieve society's goals. At the core of political economy are the questions: (i) what governments do and why, (ii) what governments should not do, and finally, (iii) what governments should do. Each of the three essays in this collection addresses one of these questions by evaluating the economic outcomes of a particular government action.

\subsection{The role of government}

The discussion within political economy on the proper role for government is based on two foundations. First is the above mentioned realization that people within the government have their individual agendas which at times may differ from public interest, however defined. Second, politics is considered as an exchange, where individuals agree to be coerced by the government in exchange for benefits. Even though the public choice view can be critical of government at times it also acknowledges the many potential benefits of government. That said, what is the proper role for government?

Rand (1964) argues that the indispensable foundation of a free society is the existence of individual rights. In her view, a right is a right to action, with no guaranteed outcome. The moral purpose of government then is to protect individuals' rights, which can only be violated by the use of force. Thus, the role of government should be that of a protector, with activities only in the limited areas of police, armed forces and law courts. Since government is supplied with means for using force, a binding constraint on it must be placed to prevent it from turning from a protector to a terrorizer, to protect people from the governments' use of force.

Friedman (1962) argues along the lines of Rand, bringing attention to the famous quote by president Kennedy - "Ask not what your country can do for you, but what you can 
do for your country" - by saying that this is reversing the proper order of government. In Friedman's view this quote misplaces the balance of power between citizens and the government, making government the patron and the citizen the ward. Thus, a better formulation of the relationship should be something like "What can I and my compatriots do through government." For Friedman the greatest threat to the individual pursuit of happiness is the concentration of power in the hands of uncontrolled governments. This implies a strictly defined role for governments: protecting individual freedom from enemies both outside and inside of societies, preserving the rule of law and property rights, and fostering free market outcomes. In particular, Friedman sees the free market, protected by limited government, as a necessary condition for political freedom as well. Thus, government has an important role in laying out the rules for market transactions, and in case of disputes, in providing means to solve those disputes. Beyond this, free markets should be capable of delivering the desired outcomes, be it in economic or political terms.

Buchanan (1990) focuses his attention on the choice of constraints that people decide to place on themselves and the government. The intuition behind the study of constitutional economics is that people have the freedom to choose the constraints they deem the best. But by doing this they commit to a reciprocal exchange of liberties. When people agree on a constitution, they also agree on being subjects to coercion. One important decision then to be made is the scope and range of the coercive authority. In case a constitution turns out to be bad, Buchanan argues it to be renegotiable anytime through a detour to anarchy, from which a new agreement evolves. Finally, Buchanan emphasizes the procedural aspect of agreements. As important as the outcome of an agreement is the process, the means by which one got there. 
As Hyman (1996) and Cullis \& Jones (1998), among others, have argued, there are special circumstances under which government's restricted role in society should be reconsidered. In particular, people may want to give government a less restricted role in working at the area of market failure. These include monopoly, public goods, externalities, economic stabilization, and income distribution, among others. However, expanding government's role beyond the basic functions of protection and law and order does entail some economic danger. It is well established in public finance literature that as much as governments can potentially alleviate market shortcomings, in some circumstances they may actually exacerbate the problems. Special interest effect, logrolling, pork-barrel politics, shortsightedness effect, rent seeking, lack of incentives for internal efficiency and imperfect information upon which to base policies are some times considered as typical examples.

\subsection{Two views on the efficiency of political system}

Weingast, Shepsle and Johnsen (1981) present a model of distributive policies where the benefits for a specific geographic constituency are financed through general tax revenue. That is, using a large tax base to finance projects that benefit only a concentrated group of people can potentially increase the aggregate government expenditure above efficient levels. For example, suppose a proposal of a 5\% surcharge on income levied on every citizen to build housing for $1 \%$ of population were put forth in the Congress. How then should a member of the Congress vote on the matter? What might be her chain of reasoning in deciding? Weingast et al argue that the solution for a politician is not defined in terms of economic efficiency, but rather in terms of political efficiency; that is, where marginal political benefits equal the marginal political costs. 
For instance, this implies an economically dubious incentive for the politician to inflate the size of government projects that buy inputs from their own district, in effect increasing the project size beyond efficient point. This is the main conclusion of the Weingast et al as well as many other models of political economy - a systematic bias seems to exist in public decision-making process towards projects of a larger-than-efficient size.

Becker's (1983) theory of competition among pressure groups is in essence a theory on the outcome of political income redistribution due to lobbying. In the model, several lobbying groups compete for favors, such as import tariffs and other such transfers of income, from government. The objective of pressure groups is to maximize the income of their members. As in the neoclassical economic theory, every group considers the benefits and costs of their action. The optimal amount of action for lobbyists is where marginal cost equals marginal benefit. The most successful groups in competition for limited funding are those that offer the political system most efficient projects. The successful bidders for favors shy away from proposing projects with large deadweight losses, and rather concentrate on proposals producing gains.

In the end, it is the competition among pressure groups for a limited amount of total funding - keeping their own cost/benefit calculations in mind - coupled with the public's preference for welfare improving projects that will drive the economic outcome of lobbying close to that of free competition. Since one group's gain in favors will mean a decrease in favors for another group, this incentive set-up will work towards an efficient outcome. The Becker model can also easily be extended to include the political system at large. That is, political parties compete for votes, and this competition drives them to offer such service packages to voters that maximize the electorate's utility. If one party is solely interested in 
promoting the interest of narrow special interest groups, then this would open the door for the competing party to come up with a better tailored package, in essence capturing a larger market share in the vote. Thus, in this view the potential benefits of competition are not reserved to (economic) markets only.

Both the Weingast et al and Becker models do acknowledge the presence of special interest in the workings of political systems. From the efficiency point of view, however, the models reach very different conclusions. In the Weingast et al model politicians' self-interest considerations cause overprovision of public goods, and therefore inefficiency. In Becker's model, on the other hand, competition among the pressure groups (or alternatively, parties) for limited funds (votes) results in an efficient outcome. In the end, both models have their merits in looking at the political process from one particular perspective. Furthermore, both provide a unique insight into some of the problems of our political system. This is important, since a flawed political system is also likely to have economic consequences through both the provision of public goods, and the workings of the private sector.

These two views can be understood as one part of a larger model that aims to explain the political process. The predictions of these models are directly connected to economic variables, notably the efficient allocation of resources. These models should not, of course, be seen as providing us with one comprehensive model of the political process. Rather, they are a good beginning in the effort to understand the workings and limitations of this process. The regrettable lesson these models provide is that the policies and institutions created by a given political system do not always have the desired effect. The economic outcomes of these policies and institutions may be efficient, or may not. 


\subsection{The three essays}

This dissertation consists of three essays that are titled "Government Growth and Fiscal Illusion: New International Evidence," "The Efficiency of International Development Aid," and "Entrepreneurship in Post-Socialist Economies."

Chapter two tests whether politicians use fiscal illusion to pursue their own personal goals, such as getting re-elected, with a consequence of larger government. The basic intuition behind fiscal illusion is that depending on the type of revenue structure governments choose, individuals can find it difficult to identify the exact tax burden they face. Personal tax share underestimation may cause individuals to perceive that they are getting public goods at a lower tax price (and consequently, that public officeholders are performing well). Fiscal illusion implies the existence of a potential for over-expansion of public sectors. The essay extends the national-level analysis of previous studies by including international data. The sample in this essay consists of 28 OECD countries, for which appropriate median income and public sector data was available for the years 1988 and 1993. Contrary to the fiscal illusion hypothesis, this study finds that an increase in the share of indirect taxes actually decreases the size of government as a share of GDP. It is hypothesized that this result could stem from politicians' desire to minimize the political resistance for tax increases.

Chapter three evaluates the effectiveness of international development aid. As is almost uniformly accepted, development aid from wealthy to developing countries is a just cause. However, the economic results from development aid in the last 40 years have not been as good as the international community would have wished. This study looks at the effect of development aid on economic growth for the years 1975-1998 for 86 developing countries. The results indicate a negative relationship between development aid and economic growth. It 
is hypothesized that these results may emanate, among other things, from the harmful incentive aid imposes upon work effort, and from tied aid that may lead to misallocation of recipient countries' scarce resources.

Chapter four about entrepreneurship in post-socialist economies examines how different types of government intervention affect entrepreneurial activity. Previous literature on transition has clearly demonstrated the importance of entrepreneurs for economic growth. The crucial question then is how governments can facilitate the creation of new enterprises. The sample in the empirical study covers 10 Baltic and Central-European transition economies for the years 1995-2000, and focuses on how various reforms (policies, institutions) initiated by governments have affected the level of entrepreneurship. Variables considered include the quality of infrastructure, rule of law, openness to trade, monetary stability and corruption, among others. The results of this essay indicate that to be successful in creating entrepreneurs, the presence of economic freedom and "good" policies - such as low taxes, low regulations, and secure private property rights - is of crucial importance. 


\section{GOVERNMENT GROWTH AND FISCAL ILLUSION:}

\section{NEW INTERNATIONAL EVIDENCE}

There are several reasons why taxpayers may find it difficult to precisely estimate their tax burden. First, taxpayers often face many different types of taxes, and the more taxes there are, the more difficult it is for taxpayers to assess their total tax liability. This relationship is made even more difficult because some taxes may be more visible to taxpayers than others.

Personal income taxes are generally more visible than excise taxes, for example. Second, because of tax shifting, actual tax incidence is often uncertain. Taxpayers would find it impossible in most cases to know how much tax is incorporated into the market prices they pay or income they earn. Third, individuals may fail to fully incorporate into their calculations the costs of compliance with the tax system. These costs can be substantial in terms of both money and effort. ${ }^{1}$ Modern tax codes tend to be extensive in size - measuring into the thousands of pages - and in constant change - with hundreds of annual revisions. As a result, there has been a flourishing and expanding market for tax consultant services, and particularly lately, for tax preparation software. ${ }^{2}$

Fiscal illusion is the term generally used to describe a misperception of the amount of taxes an individual pays. Ultimately, economics is the study of how scarce resources are allocated. To reach an efficient allocation, however, individuals need to be sufficiently informed - free of illusions at least- about the choices available to them. If individuals do not fully recognize the extent of their personal tax burden, they may not be able to make the same decision with regard to, say, the size of public sector, as they would with more accurate

\footnotetext{
${ }^{1}$ Some U.S. studies have estimated the compliance costs in the range of $\$ 386-772$ per adult; see Gale (1999).

${ }^{2}$ Bartley (2001) claims that more than half of all taxpayers in the U.S. in 1999 hired professional help to prepare their tax form.
} 
information. Adding to this problem is the inherent incentive for agents of government to expand their budgets by attempting to alter the tax code in a manner that lessens the visible cost of government to taxpayers. This makes the subject of fiscal illusion relevant not only to economics in particular, but also to the welfare of societies in general. By designing tax structures that would lessen fiscal illusion, decision makers could enable individuals to make better choices. However, political incentives often lead in the other direction. Ideally these better choices could result in a more efficient allocation of scarce resources.

This paper analyzes whether the complexity of a nation's revenue structure is a statistically significant variable in explaining government expenditure as percentage of GDP. The sample consists of 28 OECD countries, for which appropriate median income and public sector data are available for the years 1988 and 1993. The paper is structured as follows. There is a brief section on the concept of the fiscal illusion, and the forces behind it. Then, previous literature on fiscal illusion is explored and some methodological issues are raised. Next, the relationship between government size and tax structure, and economic growth is investigated. Finally, an econometric model, results from regressions, and conclusions are presented.

\subsection{Introduction to fiscal illusion}

As discussed previously, fiscal illusion refers to a situation in which taxpayers potentially misjudge the true tax burden they face, and thereby, the cost of the public sector. Generally, it is believed that this takes place in the form of underestimation, or, in other words, overestimation of the net benefits of government because of the incentives faced by agents in 
the public sector. If true, this may lead to government sizes larger than would prevail in the presence of fully informed taxpayers.

Assuming that fiscal illusion exists, a relevant question remains why rational people would allow it to prevail, especially if in contradiction to their personal interests. Intuitively, one would expect people to get rid of the illusion in the same fashion as they rid themselves of making bad choices in their daily lives. Indeed, if the lack of information vis-à-vis the cost of government has any economic significance to the voters, economic theory suggests that people would devote some time to update their information in order to evaluate the marginal benefits and costs of policy alternatives in elections. That is, given scarcity and the existence of individual budget constraints, rational people would strive for the optimal use of their funds. Interestingly, though, this may not happen in the case of choosing government size in elections. But, as Buchanan (1967) notes, the reason for this apparent failure may not be the lack of individual rationality, but rather the presence of it. People under illusion may still act in a consistent way, making good choices among alternatives.

Downs (1957) argued almost a half a century ago that voters have little incentive to be informed about the size of government. This is because the probability of casting a decisive vote is essentially zero. Since the expected benefit of the act of voting is zero for an individual, but the cost of acquiring information is considerable, people have little incentive to vote at all. That nearly half of voters do vote, say, in presidential elections, must be explained using some other reasoning, such as individuals deriving utility from the act of voting, being ethical, or minimizing regret. If Downs is right, voters would not then really have much reason to spend some of their valuable time on finding out about the level of their personal tax burden, or the fiscal illusion, either. Since a single vote will not be decisive for the size of 
government, individuals feel they have better uses for their time than finding out about the size of government, a parameter they cannot affect.

Olson's $(1965,1982)$ argument regarding collective action may also partially explain the posited possible persistence of fiscal illusion. To begin with, Olson notes that some take it for granted that if everyone in a group of individuals or firms has an interest in common, then there would be a tendency for the group to seek to further this interest. But according to Olson this is fundamentally wrong for several reasons.

First, the benefits of a given policy action tend to widespread. Therefore, any single individual in a large group with a common interest will reap only a small share of the potential gains. On the other hand, the sometimes considerable cost (time, effort, etc.) of the drive for a change in a particular policy action by government, is paid by a much more concentrated group, or maybe even just by a few individuals. Second, free riding is a serious impediment for collective action since the gains go to everyone in the group, regardless of contribution or effort. Third, it is generally the case that the more participants, the more difficult it is to agree on targets. Thus, political entrepreneurs who attempt to organize collective action are more likely to succeed if they strive to organize groups that are either small and/or consist of people with similar opinions. A group of all taxpayers, though, hardly fits that description.

The paradox of the logic of collective action then becomes that large groups, such as taxpayers, may not act in their group interest because of widespread benefits and concentrated costs, free-riding and the difficulty in agreeing on targets. If, for example, the public sector were beyond some preferred size, the process to bring it back to the preferred size would not 
be automatic. Also, one could expect any proposal for change to face vigorous resistance from those concentrated groups that are benefiting from a larger government.

Another way to look at forces behind fiscal illusion is to analyze who would be the beneficiaries from it, and its putative consequence, increasing government size. For one, politicians would seem to be one group which is clearly better off with increasing government size. If voters perceive, due to the miscalculation of the true cost of public goods, that they are getting public goods for a very low price, then they are more likely to think favorably of elected officeholders, increasing their chances of re-election. Consequently, as Puviani (1903), Buchanan (1967), and Buchanan \& Brennan (1980) note, politicians have an incentive to preserve, or even increase the extent of fiscal illusion. Indeed, if true, one would expect politicians to advocate tax structures that are complex and entail some fiscal illusion elements, and at the same time make sure that voters are highly informed about the level of public goods provided. That is, reducing the visibility of the cost (tax) side, but increasing the visibility of the benefit (spending) side. The latter goal can be achieved by keeping the spending structure simple, immediate and easy to see. The existence of special interest groups and their influence on the political process, however, may not make the pursuit of a complex revenue and/or simple spending structure always optimal for the politicians. Hettich \& Winer (1988), for instance, suggest that politicians are in the business of minimizing the resistance for new taxes. This implies that an optimal tax structure from the point of view of politicians would be one in which the taxpayer resistance for a one dollar increase in taxes would be the same for every tax category. As mentioned, fiscal illusion does not necessarily imply such a tax structure. 
Yet other motives exist why politicians may want to hide the full burden of taxation. It is well known that taxes affect work incentives, i.e., the higher the taxes, the higher the likelihood of individuals substituting leisure for work. Taxes in disguise can then in some special cases be considered, as Holzman (1950) points out, as an attempt by the decision makers to maintain the national work effort at a level higher than would prevail if individuals perceived their tax share correctly. Holzman argues that the above 'beneficial' side effect of fiscal illusion, i.e., that workers are more sensitive to changes in wages than to changes in prices, was well understood by the Soviet economic planners, and put into effective use through the means of non-uniform commodity taxation.

Instead of a deliberate design by politicians, Gale (1999) argues that the complexity of revenue structure may be an inadvertent effect of tax trade-offs that we consider worth pursuing. For instance, people want taxes to be fair, conducive to economic prosperity and respectful of individuals' privacy and, for example, social and environmental preferences. But all these desirable goals can be mutually inconsistent in terms of tax policy. Then, to achieve a reasonable balance between the aforementioned goals, a variety of tax instruments are called for. Complexity-increasing measures are also sometimes needed to close down tax evasion loopholes. Furthermore, Misiolek \& Elder (1988), among others, have argued that a diversified, i.e. fragmented, tax base may reduce the effects of business cycles on tax revenue variability, causing less fiscal stress.

Buchanan (1967) credits Italian Amilcare Puviani (1903) for being among the first modern day researchers to pay serious attention to fiscal illusion. In essence, Puviani argued that the way institutions are set up affect choices individuals make in matters such as the amount of taxes. Puviani developed a model of ruling-class in which a dominant group 
(politicians) tries to impose its will on a dominated group (taxpayers). In particular, the former attempts to extract extra funds from the latter, and then use those funds for the provision of public goods of their choice. Since taxpayers are likely to resist extra taxes from which they do not gain corresponding benefits, the task of the politicians then becomes to create a fiscal structure, fiscal illusions, of a type that minimizes taxpayer resistance for any level of tax revenues.

\subsection{Revenue structure and fiscal illusion}

Many researchers, such as Shearman (1891), Puviani (1903), Wicksell (1958) and Buchanan (1967), over the years have argued about the potential of the revenue structure to affect public spending. Wagner (1976) was the first to examine the hypothesis empirically, testing the budgetary consequences of the varying complexity of tax structures of the 50 largest U.S. cities, using data from the 1967 Census of Governments and the 1970 Census of Population. Total personal income, intergovernmental revenue, percentage of population below poverty level, population density, average salary of city employees and simplicity of the city's revenue structure were among the independent variables that were regressed on the total current expenditure of the cities. To define the tax structure, the Census Bureau classification of the sources of tax revenue was used and numerical values to cities were assigned using Herfindahl index. ${ }^{3}$

Wagner's findings strongly supported the hypothesis that the degree of simplicity/complexity of revenue structures affects public expenditure. The regression results implied that the simpler the tax structure, and the easier it is for taxpayers to perceive the real

\footnotetext{
${ }^{3}$ The four categories used were: (1) Property taxation (2) General sales taxation (3) Selective excise taxation (4) Charges and fees, excluding utility revenue. The Herfindahl index values for cities varied from 0.265 (Phoenix) to 0.815 (Indianapolis), average being 0.44 .
} 
cost of government, the more likely it is that the government has a smaller expenditure, and vice versa. In fact, if all the 50 cities were assigned the index value associated with the simplest tax structure in the sample (Indianapolis), the predicted overall public expenditure of the sample would have declined by $22 \%$ per annum.

As Oates (1988) and Dollery \& Worthington (1996) note, studies after Wagner have reached mixed conclusions concerning the hypothesis that the complexity of tax structure is a statistically significant variable in generating changes in public revenues or expenditure. Clotfelter (1976), Munley \& Greene (1978), Misiolek \& Elder (1988) and Henrekson (1988) have found no or only scant evidence in support of the hypothesis. On the other hand, Pommerehne \& Schneider (1978), Baker (1983), Breeden \& Hunter (1985), Cullis \& Jones (1987) and Heyndels \& Smolders (1995) all found a positive relationship between the complexity of the tax structure and tax revenues, a finding in the direction of what is predicted in the fiscal illusion literature. ${ }^{4}$ The next section considers some possible reasons for these contradictory results.

\subsection{Methodological considerations}

The measure of tax complexity is of paramount importance in the study of fiscal illusion. For modeling, a few alternatives present themselves. The almost uniformly used measure of tax complexity in previous literature is Herfindahl index. It is calculated based on the number of tax types in use and their respective share in total revenues. ${ }^{5}$ When the number of tax bearing

\footnotetext{
${ }^{4}$ All the aforementioned studies covered one country and either local, state or federal level. The countries included the U.S., Switzerland, Sweden, Australia, the U.K. and the Netherlands.

${ }^{5}$ For example, country A collecting $95 \%$ of its revenues from income taxes and the remaining $5 \%$ from excise taxes would have an index number of $(0.95)^{2}+(0.05)^{2} \approx 0.91$ for tax complexity. In contrast, country B collecting its revenues equally from both sources would have an index number of $2 \times(0.50)^{2}=0.50$ for complexity, and so on. In this case of only two taxes, the index numbers for most and least visibility of taxes would then run from 1.00 to 0.50 , respectively. In terms of the Herfindahl index, the tax system of country A
} 
transactions increases, and new types of taxes are introduced, the taxpayer can hardly follow with the same ease as in the case of only one type of tax. Thus, if decision makers want to amplify the level of fiscal illusion, this could be achieved by fragmenting the tax base into pieces as small as possible. Even though the use of Herfindahl index has intuitive appeal, it is far from being a perfect measure of tax complexity, since it assumes that different types of taxes have the same potential to deceive individuals and create illusion. ${ }^{6}$

Already a century ago Wicksell (1896) noted that indirect taxes in particular provide an opportunity for governments to increase "public [...] expenditure in the quiet." Later findings, such as Cullis \& Lewis (1985), Gemmell et al (1999) and Tyran \& Sausgruber (2000), seem to substantiate this proposition. If so, the use of Herfindahl index fails to adequately capture any difference accounted for by the use of more indirect (versus direct) taxes, and therefore, results in a misspecified model. Thus, the widespread use of this index in isolation may actually explain part of the contradictory results in fiscal illusion studies so far. Indeed, despite some occasional advances, the microeconomic foundations of how taxpayers identify their personal tax burden is still largely missing. No theoretical guidance currently exists as for choosing any of the values to be used in the formula. Without a doubt, by carefully choosing the parameter values for the Herfindahl index fiscal illusion can be shown to be significant in regressions. But since the values themselves are still more or less

would be considered less complex than that of country B. To understand the essentials of the tax system of country A, it would be sufficient for individuals to learn the characteristics of just the dominant tax type. In country B, on the other hand, one would have to get familiar with both types of taxes. Thus, the relative share of a tax type in total revenues plays a crucial role in calculating the index. Consequently, it generally assigns low numbers - high complexity - to systems that rely on many tax types to collect revenue, and vice versa. ${ }^{6}$ Analyzing the previous examples will highlight a potential bias in the use of Herfindahl index. For example, suppose that that the revenue share numbers of the previous example stay the same, but the sources of revenue are reversed. Now, 95\% of all tax revenues for country A come from excise taxes and the remaining 5\% from income taxes. After incorporating these changes into the tax complexity formula above, the index number remains unchanged at 0.91 . The tax system, though, has gone through a complete overhaul. The Herfindahl measure of tax complexity thus assumes that income and excise taxes, for example, are equally visible to taxpayers. 
arbitrarily chosen, this does not seem like a very satisfying approach. Even though it is quite possible that some of the values used in fiscal illusion studies so far could turn out to be correct later, the fact remains that we currently simply don't know whether that is the case or not.

In light of the obvious limitations to the use of Herfindahl index, a better approach in terms of modeling fiscal illusion may be to go back to basics and try to build a more robust empirical foundation for how people identify their tax burden from various types of taxes. In the last 20 years both survey type techniques and laboratory experiments have been used. In particular, the latter seems to hold a fair amount of promise. For example, some current laboratory evidence suggests that a clear difference exists in the perception of direct versus indirect taxes, the former being considerably more visible to taxpayers.

Thus, instead of using Herfindahl index, it may be more fruitful to use various indirect and direct tax measures as proxies for tax complexity. Even though these measures are in no means immune to the same reservations that apply to Herfindahl based indexes, their microfoundations, however imperfect they may be, are still stronger than those of fragmentation based measures. Finally, the fact that the previous literature on fiscal illusion has reached contradictory results may be attributed to two potential sources. First, the fiscal illusion measures may have been inadequate. Second, as mentioned earlier, if Hettich \& Winer (1988) are correct, it may be that creating fiscal illusion is not the prime objective of politicians at all. It actually may be just a by-product of politicians' desire to minimize tax resistance. This could potentially explain why previous research has found fiscal illusion in some locales but not in others. 


\subsection{Government size, tax structure and economic growth}

In a recent study on government size and economic growth, Gwartney, Lawson \& Holcombe (1998) analyzed international data on 60 countries since the 1960's. They found that countries spending mostly on the core functions of government, such as legal and physical infrastructure and national defense, had governments that grew significantly faster in the period 1960-1996 than their counterparts with larger budgets. ${ }^{7}$ In the five economically fastest-growing countries, the government's share of the GDP was approximately 20 percent, versus the OECD average of nearly twice that. Furthermore, the authors made a conjecture that the optimal government size in terms of economic growth is near the point of only fulfilling the core functions of government, estimated at $15 \%$ of GDP, after which every 10 percent increase in government expenditures will decrease annual economic growth by 1 percent.

This may be because higher expenditure means higher taxes, and at some point the incentives to invest, take risks and engage in productivity-enhancing activities will decrease. Instead of working for extra income people opt for leisure, a choice reducing output. Second, the larger the government grows, the higher the likelihood that it will face diminishing returns in its projects. When the marginal return on investment for the government falls to a level below that of the market sector, the allocation of resources is no longer optimal, resulting in slower economic growth. Finally, thanks to the price-system and competition between firms, the market sector is capable of adjusting fairly quickly for changes in economic environment, allocating resources to their most efficient uses. However, the structure and changes in

\footnotetext{
${ }^{7}$ Hansson \& Henrekson (1994) reach results similar to the above by analyzing the effect of government spending on total factor productivity.
} 
government spending rely on the political process that is slow by its nature. Consequently, the reallocation of resources takes longer.

Not surprisingly, beside the absolute level of government spending, a country's tax structure also seems to matter in economic growth. Using cross-sectional data from 23 OECD countries for the period 1965-1990, Widmalm (2001) found a significant negative correlation between personal income tax and economic growth. Furthermore, an increasing tax progressivity was shown to be associated with slower economic growth. The use of consumption taxes as a revenue source seemed to be less harmful to growth then the use of personal income taxes. This is possible, because in the case of consumption taxes the average tax rate is decreasing in income, as compared to the opposite effect for increasing tax progressivity. Thus, both the level of tax revenue and its sources - the tax mix - seem to play a role how well societies do economically.

\subsection{The model and empirical results}

The model to be used in this paper is based on the well-known contribution by Meltzer \& Richard (1983). It is assumed that the median voter is decisive in choosing the level of government spending, i.e., individuals below median income will vote for increases in income transfers whereas people above will vote against those income transfers. Thus, government growth over time is explained by changes in the relative position of the median voter in the adult population. If the median voter has an income below that of the mean income in society, one would expect an increase in the demand for government provided goods and services financed through redistribution. In regressions the ratio of median to mean income for households is used as a proxy to describe the decisive voter. 
The model presented below follows Mueller (1989). Suppose all government activity consists of income redistribution, denoted as r. Balanced budget implies that

$$
r=t \cdot \bar{y}
$$

where $\mathrm{t}$ is tax rate and $\bar{y}$ mean per capita income. Each individual has to choose between leisure (1) and consumption (c):

$$
\begin{aligned}
& l=1-n, \text { and } \\
& c=(1-t) y+r
\end{aligned}
$$

where $\mathrm{n}$ is the fraction of time worked. Each individual's income depends on his personal productivity $(\mathrm{x})$, resulting in income of

$$
y=n \cdot x
$$

Since $t$ and $r$ are exogenous variables in the model, each worker is left to choose $n$, i.e., how much to work. Thus, individual's maximization problem can be stated as Max U(c,l) with respect to n, subject to (2), (3), and (4). Solving the above yields the first order condition of

$$
U_{l} / U_{c}=(1-t) x
$$

i.e., the marginal rate of substitution between leisure and consumption equals the after tax marginal product of an individual's time. Finally, substituting the Stone-Geary utility function of the form $U=\ln (c+\alpha)+a \cdot \ln (1+\beta)$ to (5), one can solve the optimal $\mathrm{n}$ as

$$
n=[(1-t)(1+\beta) x-a(r+\alpha)] /(1-t)(1+a) x
$$

Those working choose a welfare maximizing point from the curve $r=y t$, in particular, the point at which the difference between $\mathrm{r}$ and t provides them the highest utility. Given $\mathrm{x}$ small enough, some individuals will entirely refrain from working. These individuals would vote for a $\mathrm{t}$ that maximizes their income transfer from taxes paid to the common pool. However, 
since $\partial y / \partial t<0$, i.e., taxes decrease willingness to work and therefore, national income, the utility maximizing tax rate for this group is increasing only up to a point. Since all voters are assumed to have identical utility functions but differences in their abilities, rational voters with low x prefer high $t$, and vice versa. As a result, if the median voter's income is below the mean income for society, he would try to close the gap by voting for increased income transfers.

The model specified is demand driven, i.e., it is assumed that demand factors solely determine the level of public goods supplied. The model to be regressed is:

\title{
GOVERNMENT EXPENDITURE AS PERCENTAGE OF GDP ${ }^{8}=$
}

\author{
$\beta_{0}$ Constant + \\ $\beta_{1}$ Share of females in labor force + \\ $\beta_{2}$ Share of elderly in population + \\ $\beta_{3}$ Share of trade in GDP + \\ $\beta_{4}$ Urbanization rate + \\ $\beta_{5}$ Per capita GDP + \\ $\beta_{6}$ Population + \\ $\beta_{7}$ Ratio between median voter's income and the mean income + \\ $\beta_{8}$ Median voter's share in total taxes + \\ $\beta_{9}$ Dummy $1993+$ \\ $\beta_{10}$ Fiscal illusion measures (Herfindahl index, Hannah-Kay index, share of indirect taxes, \\ ratio of direct to indirect taxes, in various specifications)
}

Table 2.1. describes the variables in detail, and how they are expected to affect government expenditure as a percentage of GDP. Table 2.2. presents the results of the regression analysis for the size of government.

\footnotetext{
${ }^{8}$ Double-log specification. The choice of variables follows that of previous studies on fiscal illusion, as listed at the end of section 2.2.
} 


\section{Table 2.1. Variable explanations and expected signs}

Variable

Explanation

Expected sign

Government expenditure

Share of females in labor force

Share of people 65 years of age and older in total population

Share of trade

Urbanization rate

Per capita GDP

Population

The ratio between median voter's income and the mean income

Median voter's share in total taxes

Dummy 1993
Government expenditure as a percentage of GDP.

n.a.

The higher the participation rate, the more demand there is for government provided services - such as day care and schooling - that have previously been taken care of by females.

The higher the share of retired people in society the higher the demand for income redistribution

Movements towards freer trade usually result in employment losses in sectors of non-comparative advantage.

Consequently, workers in those sectors will organize and through special interest groups demand income redistribution to share part of the national gain from freer trading.

Urbanization leads to social conflicts that call for increased spending on law and order, among other things.

Rising incomes increase demand for goods and services, such as basic sanitation, health care and education, in which' provision governments have frequently had a central role. Assuming that government provided goods are normal goods, the income elasticity of demand for public goods is between one and zero (rising at a decreasing rate).

Due to non-excludability and economies of scale, the average cost of providing public goods decreases with increasing population, resulting in increased demand for public goods.

The farther away the decisive median voter is in terms of income from society's average income, the higher the demand for income transfers to close the gap.

Measures the cost of the public goods. The lower the number the higher should the demand be for public sector goods and services. Median voter's share in total taxes = [Average Tax Rate * Median Income]/Total Tax Revenue, where ATR = (Total Tax Revenue/GDP).

Dummy variable taking a value of 0 for 1988 and 1 for 1993 . n.a. 
Herfindahl index of tax $\quad \sum_{i=n}^{n} R_{i}^{2}$, where $\mathrm{n}$ refers to the number of tax categories
complexity

and $\mathrm{R}$ to the share of each tax category in total tax revenues. A measure of fragmentation of a tax system. The higher the index, the more visible the taxes. The index was calculated separately with six, nine and eleven tax categories.

Weighted Herfindahl index of tax complexity

Hannah-Kay index of tax complexity

The share of indirect taxes in total tax revenues

The ratio of direct to indirect taxes $\sum_{i=1}^{n}\left(\phi_{i} R_{i}\right)^{2}$, where $\mathrm{n}$ refers to the number of tax categories,

$\phi$ to the weight assigned to each category and R to the share of each tax category in total tax revenues. A measure of fragmentation of a tax system. The higher the index the more visible the taxes. Using the findings of Tyran \& Sausgruber (2000), $\phi$ was assigned a value of 0.73 for indirect and 1 for direct taxes. The index was calculated with nine tax categories.

$\left(\sum_{i=1}^{n} R_{i}^{\alpha}\right)^{(1 / 1-\alpha)}$, where $\mathrm{n}$ refers to the number of tax

categories, $\alpha$ to the weight assigned to each observation and $\mathrm{R}$ to the share of each tax category in total tax revenues. A measure of fragmentation of a tax system. The higher the index the more visible the taxes. Using the findings of Heyndels \& Smolders (1995), $\alpha$ was assigned a value of 0.9. The index was calculated with nine tax categories.

Indirect taxes are harder to identify than direct taxes, such as personal income taxes, and may therefore lead taxpayers to underestimate their personal tax burden. Two specifications were used. For details, see Appendix A.4.

When the relative share of direct taxes in total taxes rises, the visibility of taxation should improve, lessening fiscal illusion. For details, see Appendix A.4. 


\section{Table 2.2. Estimates of the combined 1988 and 1993 expenditure equations}

Dependent variable: Government size as a \% of GDP

\begin{tabular}{|c|c|c|c|c|c|c|c|c|}
\hline Equation & 1 & 2 & 3 & 4 & 5 & 6 & 7 & 8 \\
\hline Constant & $\begin{array}{l}-0.87 \\
(0.56)\end{array}$ & $\begin{array}{l}-0.48 \\
(0.30)\end{array}$ & $\begin{array}{l}-1.15 \\
(0.72)\end{array}$ & $\begin{array}{l}-0.72 \\
(0.46)\end{array}$ & $\begin{array}{l}0.16 \\
(0.10)\end{array}$ & $\begin{array}{l}1.75 \\
(0.95)\end{array}$ & $\begin{array}{l}0.48 \\
(0.32)\end{array}$ & $\begin{array}{c}0.97 \\
(0.63)\end{array}$ \\
\hline $\begin{array}{l}\text { Share of females } \\
\text { in labor force }\end{array}$ & $\begin{array}{c}0.49 \\
(1.64)\end{array}$ & $\begin{array}{c}0.44 \\
(1.47)\end{array}$ & $\begin{array}{r}0.50 * \\
(1.69)\end{array}$ & $\begin{array}{r}0.50^{*} \\
(1.70)\end{array}$ & $\begin{array}{c}0.40 \\
(1.38)\end{array}$ & $\begin{array}{c}0.32 \\
(1.10)\end{array}$ & $\begin{array}{l}0.33 \\
(1.21)\end{array}$ & $\begin{array}{c}0.26 \\
(0.94)\end{array}$ \\
\hline $\begin{array}{l}\text { Share of elderly }(65+) \\
\text { in population }\end{array}$ & $\begin{array}{l}0.73 * * * \\
(6.01)\end{array}$ & $\begin{array}{l}0.74 * * * \\
(6.12)\end{array}$ & $\begin{array}{l}0.72 * * * \\
(5.96)\end{array}$ & $\begin{array}{l}0.72 * * * \\
(5.92)\end{array}$ & $\begin{array}{l}0.73 * * * \\
(6.26)\end{array}$ & $\begin{array}{l}0.81 * * * \\
(6.81)\end{array}$ & $\begin{array}{l}0.79 * * * \\
(7.04)\end{array}$ & $\begin{array}{l}=0.84 * * * \\
(7.21)\end{array}$ \\
\hline $\begin{array}{l}\text { Share of trade } \\
\text { in GDP }\end{array}$ & $\begin{array}{l}0.19 * * \\
(2.16)\end{array}$ & $\begin{array}{l}0.13 \\
(1.35)\end{array}$ & $\begin{array}{l}0.21 * * \\
(2.30)\end{array}$ & $\begin{array}{c}0.12 \\
(1.15)\end{array}$ & $\begin{array}{l}0.19 * * \\
(2.40)\end{array}$ & $\begin{array}{l}0.24 * * * \\
(2.99)\end{array}$ & $\begin{array}{l}0.27 * * * \\
(3.35)\end{array}$ & $\begin{array}{l}=0.25 * * * \\
(3.22)\end{array}$ \\
\hline $\begin{array}{l}\text { Urbanization } \\
\text { rate }\end{array}$ & $\begin{array}{c}0.12 \\
(0.65)\end{array}$ & $\begin{array}{l}0.19 \\
(1.07)\end{array}$ & $\begin{array}{l}0.12 \\
(0.67)\end{array}$ & $\begin{array}{c}0.21 \\
(1.08)\end{array}$ & $\begin{array}{c}0.40 \\
(0.23)\end{array}$ & $\begin{array}{l}0.85 \\
(0.52)\end{array}$ & $\begin{array}{l}0.85 \\
(0.54)\end{array}$ & $\begin{array}{c}0.43 \\
(0.27)\end{array}$ \\
\hline Per capita GDP & $\begin{array}{l}-0.45 \\
(0.87)\end{array}$ & $\begin{array}{l}-0.61 \\
(1.16)\end{array}$ & $\begin{array}{l}-0.26 \\
(0.43)\end{array}$ & $\begin{array}{l}-0.50 \\
(0.98)\end{array}$ & $\begin{array}{l}-0.53 \\
(1.06)\end{array}$ & $\begin{array}{l}-0.16^{* *} \\
(2.38)\end{array}$ & $\begin{array}{l}-0.12 * * \\
(2.26)\end{array}$ & $\begin{array}{l}-0.20 * * * \\
(2.87)\end{array}$ \\
\hline Population & $\begin{array}{c}0.19 \\
(0.00)\end{array}$ & $\begin{array}{l}-0.25 \\
(0.58)\end{array}$ & $\begin{array}{c}0.44 \\
(0.10)\end{array}$ & $\begin{array}{l}-0.30 \\
(0.61)\end{array}$ & $\begin{array}{l}0.58 \\
(0.15)\end{array}$ & $\begin{array}{l}0.22 \\
(0.55)\end{array}$ & $\begin{array}{c}0.50 \\
(1.20)\end{array}$ & $\begin{array}{c}0.31 \\
(0.80)\end{array}$ \\
\hline $\begin{array}{l}\text { Ratio of median } \\
\text { to mean income }\end{array}$ & $\begin{array}{l}-0.68 \\
(1.38)\end{array}$ & $\begin{array}{l}-0.68 \\
(1.39)\end{array}$ & $\begin{array}{l}-0.75 \\
(1.51)\end{array}$ & $\begin{array}{l}-0.70 \\
(1.43)\end{array}$ & $\begin{array}{l}-0.57 \\
(1.18)\end{array}$ & $\begin{array}{l}-0.31 \\
(0.63)\end{array}$ & $\begin{array}{l}-0.39 \\
(0.83)\end{array}$ & $\begin{array}{l}-0.17 \\
(0.35)\end{array}$ \\
\hline $\begin{array}{l}\text { Median tax share } \\
\text { of an individual }\end{array}$ & $\begin{array}{l}-0.88 \\
(0.52)\end{array}$ & $\begin{array}{l}-0.92 \\
(0.55)\end{array}$ & $\begin{array}{l}-0.10 \\
(0.60)\end{array}$ & $\begin{array}{l}-0.10 \\
(0.62)\end{array}$ & $\begin{array}{l}-0.42 \\
(0.02)\end{array}$ & $\begin{array}{l}0.63 \\
(0.37)\end{array}$ & $\begin{array}{l}0.12 \\
(0.71)\end{array}$ & $\begin{array}{c}0.11 \\
(0.68)\end{array}$ \\
\hline
\end{tabular}

\begin{tabular}{|c|c|c|c|c|c|c|c|c|}
\hline $\begin{array}{l}\text { Herfindahl index } \\
\text { (six tax categories) }\end{array}$ & $\begin{array}{l}0.96 \\
(0.41)\end{array}$ & -- & -- & -- & -- & -- & -- & -- \\
\hline $\begin{array}{l}\text { Herfindahl index } \\
\text { (nine tax categories) }\end{array}$ & -- & $\begin{array}{l}-0.15 \\
(0.92)\end{array}$ & -- & -- & -- & -- & -- & -- \\
\hline $\begin{array}{l}\text { Herfindahl index } \\
\text { (eleven tax categories) }\end{array}$ & -- & -- & $\begin{array}{c}0.90 \\
(0.70)\end{array}$ & -- & -- & -- & -- & -- \\
\hline $\begin{array}{l}\text { Weighted Herfindahl inde } \\
\text { (nine tax categories) }\end{array}$ & & -- & -- & $\begin{array}{l}-0.11 \\
(0.77)\end{array}$ & -- & -- & -- & -- \\
\hline $\begin{array}{l}\text { Hannah-Kay index } \\
\text { (nine tax categories) }\end{array}$ & -- & -- & -- & -- & $\begin{array}{l}-0.22 * \\
(1.73)\end{array}$ & -- & -- & -- \\
\hline
\end{tabular}

\begin{tabular}{|c|c|c|c|c|c|c|c|c|}
\hline $\begin{array}{l}\text { Share of indirect taxes } 1 \\
\text { (specification 1) }\end{array}$ & -- & -- & -- & -- & -- & $\begin{array}{l}-0.34 * * \\
(2.36)\end{array}$ & -- & -- \\
\hline $\begin{array}{l}\text { Share of indirect taxes } 2 \\
\text { (specification } 2 \text { ) }\end{array}$ & -- & -- & -- & -- & -- & -- & $\begin{array}{l}-0.28 * * * \\
(2.87)\end{array}$ & -- \\
\hline $\begin{array}{l}\text { Ratio of direct to indirect } \\
\text { taxes }\end{array}$ & -- & -- & -- & -- & -- & -- & -- & $\begin{array}{l}0.23 * * * \\
(2.94)\end{array}$ \\
\hline Adjusted $\mathrm{R}^{2}$ & 0.66 & 0.67 & 0.66 & 0.66 & 0.68 & 0.70 & 0.72 & 0.72 \\
\hline
\end{tabular}

Notes: Double log specification, absolute t-values in brackets. ***,**,* denotes significance at the $1 \%, 5 \%$, $10 \%$ level, respectively. 
Overall, the specified model performs reasonably well, as can be seen from Table 2.2. Adjusted $\mathrm{R}^{2} \mathrm{~s}$ are relatively high, as are F-tests, and the regressions passed the Breusch-Pagan heteroscedasticity test without problems. Of the variables, the elderly's share in population, as well as the extent of international trade, turned out to be generally significant in explaining the size of government. The share of females in the labor force is significant in two, and per capita GDP in three, of the eight specifications. The coefficients for the urbanization rate, population, median voter, and median tax share are overwhelmingly of the correct sign, but insignificant. The constant, as well as the dummy are consistently insignificant.

The traditional fiscal illusion variables, on the other hand, performed rather poorly. Of the three conventional Herfindahl measures two of the three have a wrong sign and all are insignificant. The same applies to the weighted Herfindahl index. Of the Herfindahl index variants only the Hannah-Kay measure was significant, but only at the $10 \%$ level. Put together, the Herfindahl based estimates do very little to strengthen the case for the fiscal illusion hypothesis.

The remaining three fiscal illusion measures - two variations of the share of indirect taxes and the ratio of direct to indirect taxes - were all highly significant, but of the opposite sign than conventional wisdom suggests. The regression results for the indirect tax measures indicate that a $1 \%$ increase in the share of indirect taxes (two measures) decreases government expenditure as a share of GDP by $0.34 \%$ and $0.28 \%$, respectively. On the other hand, a $1 \%$ increase in the ratio of direct to indirect taxes increases the relative size of government by $0.23 \%$.

Clearly, the results in Table 2.2. stand in contradiction to the predictions of the fiscal illusion hypothesis in suggesting that heavier reliance on visible taxes, such as income taxes, 
is associated with larger government. Or considered the other way, the use of invisible taxes, such as excise taxes, is associated with smaller government.

What could account for this finding? One possibility would be to focus on the motives of politicians who design tax structures. Even though creating fiscal illusion through less visible taxes may well seem like an attractive option to politicians, an even stronger motive in the opposite direction may also be at work here, namely, the level of taxpayer resistance towards new taxes, as suggested by Puviani. For example, suppose politicians detect a signal from their constituencies to increase government spending. However, by the nature of affairs, different tax instruments are called for when dealing with different taxpayer groups. Thus, politicians are constrained in their choice of the appropriate tax extraction devises. As a result, suppose two alternatives are discussed: a new indirect business tax can be levied either on the members of a trade lobby composed of large industrial firms, or a direct tax on general taxpayers. In all likelihood, the first group would devote considerable resources to fight any tax that would increase their cost. On the other hand, the resistance from general taxpayers would probably be much weaker. Following along the lines of Olson (1965), general taxpayers are a large, heterogeneous and unconcentrated group and the amount of the new tax per person could well end up being low enough as not to justify any group action. This is not the case for a concentrated group. Thus, in this particular case, politicians may be much more inclined to levy the tax on general taxpayers than the trade lobby.

In general then, if direct taxes tend to be levied on the general taxpayer, and indirect taxes tend to be levied on highly concentrated interest groups, one can end up with the above result which is contradictory to the one proposed by the fiscal illusion literature. In other words, the creation of fiscal illusion may not necessarily be at the top of politicians' agenda 
when devising new tax policies. This is consistent with Hettich \& Winer's (1988) argument that politicians aim to minimize tax resistance by their electorate. As argued earlier, this outcome does not suggest that the tax structure would be Pareto-efficient.

Interestingly, the findings of this study also complement those of Gwartney, Lawson \& Holcombe (1998) and Widmalm (2001) mentioned earlier. The former found that an increasing government size stifles economic growth whereas the latter found the same for an increasing use of personal income taxes, i.e. direct taxes. In this paper it was shown that the use of direct taxes may be positively related to government size, thus binding the previous two studies together.

\subsection{Conclusion}

The concept of fiscal illusion has a lot of intuitive appeal. If politicians want to look good in the eyes of voters, say, with re-election in mind, both an opportunity and an incentive would seem to exist for them to hide the true tax burden from voters. As the fiscal illusion literature focusing on revenue structure has suggested, this can be done in at least two ways. First, the revenue structure can be fragmented into many pieces. Any modern tax code with hundreds of tax categories makes it nearly impossible to calculate one's own tax load. Second, it is well known that taxpayers are able to identify some taxes more easily than others. A case in point is for example personal income taxes versus excise taxes. Thus, the real burden of taxes can also be hidden with a careful choice of type of taxes.

Using either method, or any combination of them, could cause taxpayers to underestimate the tax burden they face. Moreover, since the cost of finding out about the fiscal illusion likely far outweighs any benefits for a single taxpayer, there would seem to be a 
very small chance for politicians to be exposed in case they decide in favor of hiding the true tax burden of society. Thus, potential exists for expanding governments.

Given the clear-cut theoretical premises of the fiscal illusion literature on revenue structure, the empirical results from testing the above hypothesis have been disappointing. Even though a slight majority of fiscal illusion studies have found some support for the hypothesis, a sufficient number of studies have also found no indication of fiscal illusion, throwing the whole concept into doubt. This is not overly surprising, though, due to the reliance on current Herfindahl based measures of fiscal illusion.

Contrary to the predictions of fiscal illusion hypothesis, this study - using some alternative fiscal illusion measures - found that an increase in the share of indirect taxes in total revenue actually decreases the relative size of government, or alternatively, that an increase in the ratio of direct to indirect taxes increases the relative size of government. It was hypothesized that this result could stem from politicians desire to minimize resistance for tax increases. Consequently, it was argued, an asymmetry in the power wielded by interest groups leads the largest and most heterogeneous groups to be the ones bearing the burden of new taxes. In this study, general taxpayers and direct taxes may fulfill that condition.

Even though the sample in this study was tightly defined due to the lack of comparable international median income data, the results indicate that fresh approaches are called for in modeling the effects of tax structures on government growth. These include acquisition of new fiscal illusion measures through better methodologies, such as laboratory experiments, and increased focus on the incentive structure politicians face in designing tax structures. It also remains up to future research to show what importance taxpayer resistance plays on politicians' choice of tax instruments. This study suggests Olson's (1965) logic of collective 
action as a potential new way to model tax resistance. Overall, the central argument of this chapter highlighted the potential of political system to shape tax structure in a way that may not yield optimal economic results. Based on the discussion in chapter one about the proper role of government in society, this result suggest that it may be in the interest of societies to consider constraining the freedom of political actors in devising tax structures.

The next chapter examines the effects of international development aid on economic growth for 86 developing economies in the period 1975-1998. The central question of this chapter is whether the role western governments have taken in assisting the third world through international development aid has resulted in improved economic progress in developing countries. 


\section{THE EFFECTIVENESS OF INTERNATIONAL DEVELOPMENT AID}

In the last half century, developed countries have paid increasing attention to the problems of developing countries. Not only has the disastrously low level of economic development in large parts of the world become apparent over time, but also all the undesired side-effects of enduring poverty: poor health, widespread diseases, low life expectancy, and the general lack of means of entire nations to deal with basic needs. Wealthy countries don't necessarily have purely unselfish motives when helping poorer countries through financial aid. Part of any aid constantly flows back to donors through highly stipulated procurement contracts. Aid has also increased the potential for donors to buy preferential future treatment for the business firms of their own nationality. Politically, aid can be seen as serving to buy increased international and regional clout through new political allies, and indirectly, assuming an increased economic growth in recipient countries occurs, bringing more stability to world affairs. Furthermore, development aid is a way to advance some core values of the donors. These include influence on religious, political, or economic system choices.

\subsection{Introduction to development aid}

Despite the steady flow of development aid to poor countries in the last fifty years, the results have been somewhat disappointing, as noted by Bovard (1986), Burnside \& Dollar (2000), The World Bank (1998), Vasquez (1998), Easterly (2001), and Easterly \& Levine (2001), among others. Even though some countries, notably in East Asia, have managed to break out of poverty, many of the poorest countries have actually seen their real per capita incomes decline since the 1970s. More than one billion people still live on less than $\$ 1$ a day. Many of 
the advances in basic health care and education in the last few decades have been negated by the rapid spread of HIV/AIDS, particularly in the world's poorest countries. Given the ineffectiveness of past aid and fiscal constraints the donor countries have faced in the 1990s, a type of aid fatigue among the donors has become apparent. The long-term trend of increasing aid disbursements was broken in the mid 1990s, and has given way to a systematic reevaluation of donor-initiated development strategies.

Even if development aid has not been as effective as the international community has wished, world leaders have been consistent in signaling their determination to improve the lot of the poorest countries. The $2001 \mathrm{UN}$ conference of 140 world leaders in Monterrey reiterated further support for the Millennium Development Goals - cutting in half the proportion of people living on less than one dollar a day, eliminating gender disparity in education, reducing child mortality by two-thirds, and developing a global partnership for development, among other things - that are to be achieved by 2015. How are these goals to be achieved? The World Bank, for instance, offers essentially a two-pronged solution: first, to double the current flow of aid to developing countries, and second, a new commitment to good governance on the part of the recipient countries. This study looks at whether an increase in the level of development aid would likely result in increased growth rates for developing countries. In addition, I examine whether the quality of governance affects the results of aid.

\subsection{Theories Explaining Aid-Ineffectiveness}

What accounts for the mixed results of past aid? First, in the early era of development aid many poorer countries were either socialist, or believed, as the West did, in the Keynesian 
view of government. In particular, it was thought that market economies largely failed to selfcorrect after changes in economic environment, with adverse effects on both growth and employment. Rather, the argument goes, governments possessed the necessary tools regulation, taxation, and spending - to fix market failures that prevented economies from reaching their potential output level. Accordingly, governments played a particularly large role in the economies of poor countries. However, the Keynesian view was seriously challenged in the 1970s, and later studies, such as Gwartney, Lawson \& Holcombe (1998), have shown that after a relatively low threshold value, increasing government size as measured by a percentage of GDP stifles economic growth. Thus, the poor economic showing of less developed countries could be attributed - with or without aid - to an above-optimal share of government in economic activity. ${ }^{9}$

Not only has the proper economic role for government come under reconsideration, but changes in modeling growth have also taken place in the last decades. Robert Solow stated his well-known growth model in the 1950s. Increased accumulation of inputs, that is, capital and labor, and improved technological knowledge, were seen to be the core ingredients of economic growth in the long run. Accordingly, early development aid emphasized the importance of measures that increased input levels and technology in the recipient countries. This strategy, though, failed to achieve the desired economic results in the poorest countries. A search for new underpinnings of growth in the context of poor economies ensued.

Olson (1982, 2000) and North (1990), among others, have argued powerfully that sound institutional structures, such as property rights, law and order, and commitment to good

\footnotetext{
${ }^{9}$ The relatively low growth rates of third world countries can unlikely be explained through their different choice of desired outcomes. For instance, there is little evidence of any particular preference on their part for income redistribution measures (as measured by Gini-coefficients) rather than for economic growth.
} 
policies, are a necessary precondition for economic growth. In their view, the lack of quality institutions seriously hampers growth in underdeveloped world. Since poor countries generally lack well-developed institutions, the disappointing results of development aid can then be explained through a partially misplaced focus of aid on quantitative changes in the levels of inputs and technology. As current knowledge on development suggests, increased inputs and technology are necessary but not sufficient condition for economic growth in the least developed nations.

Yet another explanation on aid ineffectiveness deals with the incentive structure economic agents face in both developing and developed countries. For instance, Devarajan, Dollar \& Holmgren (eds.) (2001) note that donor countries have kept the levels of aid to individual countries constant over the years regardless of the economic policies of the recipients. More recently, Alesina \& Weder (2002) have further confirmed this claim. Both bad and good economic behavior have actually been rewarded equally. This soft budget constraint has created little extra incentive for countries to improve. In some cases the use of unproductive economic policies, and their consequence, a poor economic showing, may have actually led to increased levels of aid. If only a real crisis leads to economic reforms, then the non-discriminatory nature of development aid may have helped to break the healthy link between bad economic policies and institutions, and their natural economic consequence, poor economic showing, in essence prolonging the needed shift to better policies.

Vasquez (1998) suggests that donor agencies' incentive-defeating behavior in disbursing aid may be partially explained by their goal of self-preservation. Let us imagine a case where donor agencies were to refuse funds due to bad economic policies and institutions of the recipient. If the recipient then runs out of any other viable options and commits itself to 
reforms that yield good economic results, political decision-makers in the donor country would likely reduce their use of donor agencies. This would be against the interest of bureaucrats in charge of disbursing aid if they are, as Niskanen (1968) suggests, budget maximizers.

The point made by Kornai (1992) in reference to socialist systems may also apply to development aid. Namely, bureaucrats in the donor agency that executes plans may be biased towards selecting development projects that are straightforward in terms of completion. But even if these projects manage to meet all their predetermined targets, they are still not necessarily the ones that would yield the highest marginal benefits to the recipient. For instance, donor agencies may have a preference to choose easy targets over hard ones. Furthermore, this potential problem may be exacerbated by the incentives the agents at the political level face. Generally, one would expect politicians to prefer the kind of aid that yields good results. But projects that could aid the recipient the most are often difficult to accomplish - such as helping to set up new institutions - and even if successful, the possible success materializes only years after the start of funding. Thus, politicians' incentives may be aligned with those of the bureaucrats': it is better to fund relatively undemanding - highly focused - projects with high likelihood of swift and measurable success than hard projects that may fail, and therefore, taint the politicians' image with the electorate.

In addition to the ones pointed out in previous literature, some additional potential weaknesses in the donor side can be listed. First of all, understaffing can be a serious problem in a donor agency. Not only do the development agencies work in co-operation with many multilateral agencies, such as the various affiliates of the World Bank, the United Nations and regional development banks, but they also deal with hundreds of aid projects. Even though the 
thorough management of just one such fund or project could provide full-time employment for any bureaucrat, desk officers typically have to deal with a multitude of such undertakings. The donor representative may also be stationed in a different continent from the recipient, and may not have sufficient travel funding, or embassy network to keep track of daily, weekly, or even monthly developments in the aid vehicle of choice. Without a direct source person, the level of information flow can be not only poor, but of dubious quality. In sum, a lack of frequent and trustworthy information is a serious impediment to good quality bureaucratic planning.

Secondly, due to both time and resource constraints the bureaucrat faces, duties have to be prioritized. One goal becomes primary: the bureaucrat has to provide the national parliament in timely fashion documentation and requests to replenish funds and get approval for new or continued agreements negotiated on higher departmental or political levels. Furthermore, any funding earmarked for a particular project has to be released to the recipients within the budgetary deadlines set forth by the donor government. However, even after the money has been appropriated by the national parliament, its release may require considerable effort. Since even the smallest grants frequently involve millions of dollars, considerable procedural safeguards have usually been put in place to ensure the proper release. Thus, this time consuming process with sizeable amount of paperwork further dilutes the bureaucrat's ability to concentrate on issues such as monitoring the quality and effects of aid. Indeed, the biggest failure for any bureaucrat is to fall short in filing grant requests to parliaments, and then administering the grants to recipients in time. As a consequence, the avoidance of departmental or parliamentary inquiries may take precedence over other more worthwhile items on a bureaucrat's agenda. 
The organizational structure of the donor agency may also play a role in how well the donor system works. Generally, planning and administering aid is complex enough that experience greatly affects the quality of work in any donor agency. Thus, a first-rate institutional memory should be positively correlated with the quality of work. Interestingly, though, many donor agencies may be deficient in this respect. Even though some donor countries have independent agencies with lifetime contracts for bureaucrats dealing with international development cooperation, in many others the donor agency is simply one department within the ministry for foreign affairs, subjecting at least some of its civil servants to regular post circulation within the ministry every two to four years. In effect, this system forces the bureaucrats to move on just when they have accumulated efficient levels of knowledge on development issues. Even though modern computer databases somewhat ease the problem of knowledge evaporation, they are no substitute for real persons with historical knowledge.

Finally, although the importance of aid evaluation is generally understood by donor agencies, this may not translate to the status of the evaluation unit in place. If the evaluation unit is organizationally within the donor agency, serious questions of independence arise. In particular, this setup forces the evaluators to place judgment on projects managed by their colleagues. If there is post circulation within the department, an optimal survival strategy in the long term for any evaluator would be to shy away from any fundamental critique of coworkers. The top administrators may then conclude that since the aid is working there is little reason to funnel more funds to evaluation, or away from concrete development projects.

Also, project evaluation is a high-skill position that requires considerable experience in the subject. To find experts from outside the donor agency may therefore be difficult, and 
any such outside expertise would have to be compensated generously, possibly above the levels of regular bureaucrats. Since government bureaucrats as an interest group are likely to wield considerable clout on labor and compensation issues, this is likely a difficult proposition to put into practice. These problems may lead evaluation units to be chronically understaffed or have a high employee turnover, eroding the effectiveness of project evaluation.

\subsection{Previous literature}

Previous literature on development aid has looked at how aggregate flows of aid have affected economic growth of individual countries. Dalgaard, Hansen \& Tarp (2000) summarize the findings from the last 30 years and a total of 131 cross-country studies by noting that aid has increased aggregate savings and investments, though by less than the aid flow itself, and has led to increased economic growth in cases where the lack of capital base was the most important factor in holding back growth. However, when this is not the problem, this conclusion sheds little light on how to improve the growth rates in the larger group of aid recipient countries where growth lags below potential.

The most recent econometric studies have concentrated on suggesting alternative ways to reach better results from development aid. For instance, contrary to many previous findings, Boone (1996) found that in a sample of 96 recipient countries, foreign aid did not significantly contribute to investment or economic growth rates, or to an improvement in human development indicators. ${ }^{10}$ However, giving aid to politically liberal regimes did seem

\footnotetext{
${ }^{10}$ This potentially suggests the existence of a "crowding out" effect. When the aid flows in, the recipient governments may simply shift some of the pre-planned government investment to some other spending categories of choice.
} 
to lead to lower infant mortality, suggesting an alternative way and rationale to aid distribution.

In another recent study, Burnside \& Dollar (2000) studied the effectiveness of aid in a sample of 56 developing countries. The authors found that aid given to countries with good institutions and policies has a far higher likelihood to affect growth positively than aid given to countries of poor institutions and policies. For this the authors developed their own quality of governance (budget surplus, inflation, trade openness, institutional quality) measures.

Interestingly, Alesina \& Weder (2002) noted that there is little evidence that economically soundly managed countries receive more foreign aid. Thus, if the result of Burnside \& Dollar is correct, this automatically implies that aid has not been targeted as efficiently as possible. In the words of Mancur Olson (1996), \$100 bills still lie on the sidewalks of developed countries.

Using the same sample as Burnside \& Dollar, Hansen \& Tarp (2001) did find a positive relationship between foreign aid and real per capita growth, but also noted, as have Levine \& Renelt (1992) before, that the results seemed highly sensitive to regressors and econometric modeling used. However, the governance measures turned out to be significant only under conditions the authors deemed highly objectionable.

\subsection{Measuring aid and governance}

This study attempts to shed further light on the relationship between aid and economic growth. Compared to previous literature on the effectiveness of development aid, this study uses a more comprehensive governance measure in aid regressions, two alternative data sets on measuring aid disbursements, and country specific econometric modeling. Gwartney, 
Lawson, et al (2002) have constructed an economic freedom of the world index (EFW) that goes back to the year 1970, and is far more comprehensive than that used by previous studies. Instead of concentrating on only a few policy variables (budget surplus, inflation, trade openness, institutional quality), the EFW is comprised of 37 variables that fall under five general headings: size of government, legal structure and security of property rights, access to sound money, freedom to exchange with foreigners, and the level of regulations on labor, business and credit.

Even though the index by its nature ultimately relies on individual researchers' assessment of the importance of various variables to economic growth, several recent studies such as Gwartney, Lawson \& Holcombe (1999), Haan \& Sturm (1999), Wu \& Davis (1999), Heckelman \& Stroup (2000) and Ali \& Crain (2002) have confirmed its relevance as an approximate measure for governance and growth. As such, the EFW is a step forward in measuring the nature of a country's domestic policy environment, and is used in this study to approximate the quality of governance.

When measuring aid flows, most recent studies have used the OECD data set of net official development assistance, defined as transfer from a donor minus any repayment during a given period. The transfer - Official Development Assistance (ODA) - by definition includes any assistance, save military aid, with a grant element of at least $25 \%$. However, Chang, Fernandez-Arias \& Serven (1999) argue that the official net ODA figures provide a distorted measure of true aid flows, generally overstating the level of assistance, and propose a new valuation approach - Efficient Development Assistance (EDA) - for measuring true flows. In particular, EDA adjusts for the varying degrees of concessionality in loans, and uses 
a country specific discount rate in assessing the value of a transfer. In this paper I will use both net ODA and EDA to see if the choice of data set is critical for the regression results.

Econometrically, a two stage least squares fixed effects model is used. Contrary to the conventional OLS based aid studies, this allows for country-specific effects in capturing variation across countries and time shifts in the regression function. ${ }^{11}$ Procedurally, foreign aid is first regressed on a full set of control variables and a policy function created to explain aid flows. Then, the computed values from this regression are used as instruments for aid in the main regression, explaining real GDP per capita growth rates. Thus, aid is considered to be an endogenous variable on the right hand side of the regression. At the same time as the level of aid affects growth rates, growth is assumed to affect the level of aid, economically stressed countries being more likely recipients of assistance than wealthy ones.

\subsection{The model and empirical results}

The data sample covers 86 developing countries and the years 1975 - 1998. The 24 years are divided into five periods - 1975-79, 1980-84, 1985-89, 1990-94, 1995-98. Each period consists of the average for those years. The countries are listed in Appendix A. The model is written as:

$$
(\text { growth })_{\mathrm{it}}=\alpha+\gamma^{\prime}(\text { control })_{\mathrm{it}}+\beta_{1}^{\prime}(\text { aid })_{\mathrm{it}}+\beta_{2}^{\prime}\left(\text { aid }^{*} \text { policy }\right)_{\mathrm{it}}+\beta_{3^{\prime}}\left(\mathbf{a i d}^{2}\right)_{\mathrm{it}}+\varepsilon_{\mathrm{it}},
$$

the first stage equation being

$$
\operatorname{aid}_{i t}=f\left(z_{i t}\right) \text {, }
$$

where $\mathrm{z}$ refers to the instrumental variables.

\footnotetext{
${ }^{11}$ The fixed effects model was chosen over the random effects model based on the Hausman statistic. The likelihood ratio test between the one-way and two-way fixed effects model suggested the use of the latter.
} 
The dependent variable in the model is real GDP growth per capita. The independent variables are: ${ }^{12}$

Initial level of GDP per capita (log, in real \$) measures the conditional rate of convergence of the economy to its long-run position. Based on the neoclassical growth model the coefficient of the initial GDP should be negative, i.e., the higher the initial income level the slower the growth.

Population growth $(\%)$ decreases the share of capital per worker and is therefore expected to slow economic growth. This effect may be reinforced by the fact that additional productive resources are redirected for child care.

Government consumption (as a \% of GDP) approximates the public sector spending that does not contribute to an increase in nation's productivity. Thus, this measure is always less than total government expenditure. An increasing government consumption is associated with higher tax rates and lower work incentives for the population.

Human capital: (a) Secondary education (as a \% of relevant age group) measures the level of human capital that raises the skill level of population, and therefore, total productivity. (b) Life expectancy (log, in years) reflects the general health status of population, a larger number signaling a higher likelihood for economic growth.

Investment (as a \% of GDP) is one of the principal components of the neoclassical growth theory. A higher investment ratio increases the amount of capital per worker, and therefore, total productivity and economic growth.

Economic freedom of the world index (EFW, on a scale of 10) approximates the level of freedom in a society as measured by the levels of personal choice, voluntary exchange,

\footnotetext{
${ }^{12}$ The choice of variables was based on the following previous studies on economic growth: Ali \& Crain (2002), Barro (1997), Burnside \& Dollar (2000), Gwartney, Lawson \& Holcombe (1999) and Carlsson \& Lundström (2002).
} 
competition and protection of person and property. These freedoms allow for the freer working of the 'invisible hand.' A higher index number is associated with better governance, and potentially, higher economic growth.

Inflation (GDP deflator, \%) measures change in annual price level. High rate of inflation is associated with uncertainty that makes it difficult for individuals' to calculate the net benefits of any given economic activity in the future. In an environment of high/unpredictable inflation people are more likely to refrain from potentially productive projects.

Foreign aid: (a) Official development assistance (ODA, as a \% of GDP) and (b) Efficient development assistance (EDA, as a \% of GDP), according to neoclassical growth theory, are expected to raise the level of savings in society, and through investment increase the level of economic growth. On the other hand, foreign aid may also crowd out domestic investment, decrease work effort, and if tied to unproductive projects, may actually lead to slower growth.

Instruments for foreign aid: In taking into account the potential endogeneity of foreign aid in the regressions, the following variables (a policy function) is used to explain the flows of aid: (a) Level of income per capita (in \$) at the beginning of each period. Poorer countries generally get more foreign aid. (b) The amount of total population (in millions of inhabitants). Generally, smaller countries tend to receive more per capita aid than large ones. (c) Infant mortality (deaths before the age of one, per thousand) and illiteracy rate (as a $\%$ of adult population) are human development indicators that are considered as important factors when donors make decisions on granting aid. 
Table 3.1. presents the empirical findings of the study. Regressions (1) and (2) use basic OLS without group dummy variables. ${ }^{13}$ The results from the two OLS regressions yielded somewhat different results. The initial level of GDP per capita, life expectancy, investment and economic freedom of the world all turned out to be of the expected sign and significant in explaining economic growth. Inflation and government consumption were also significant in one of the two regressions. For inflation, the significance was probably due to the ODA dataset that included a few observations with inflation rates in the thousands. When the outliers were purged, inflation actually became less significant without affecting the significance of any other variable. Interestingly, all three aid variables - aid as a \% of GDP, aid interacted with freedom index, and aid squared - were insignificant, the only exception being aid squared in the EDA dataset. The two OLS regressions were able to explain about $35 \%$ of the variation in the dataset.

Regressions (3) to (10) use a fixed effect model with group dummy variables and period effects. Regressions (3) and (4) use full samples with no parameter restrictions. In regressions (5) and (6) countries that are one standard deviation or more below sample mean of the economic freedom of the world index are excluded. This tests whether excluding relatively poor governance countries from the sample would have a positive effect on aid effectiveness. Regressions (7) and (8) exclude only the very poorest governance countries the limit being two or more standard deviations from the sample mean. Here another

\footnotetext{
${ }^{13}$ The limited availability of the EFW-index observations for the period in the mid-seventies caused the datasets to be unbalanced. However, even when it would have been straightforward to extrapolate the missing observations, this was not done. Since variation in the EFW-index can not only be fairly large, but also unpredictable in direction for five year averages, it was considered better to omit some observations rather than introduce potential bias to the sample.
} 


\section{Table 3.1. Estimates of the 1975-1998 real GDP growth per capita equations}

Dependent variable: Annual real GDP growth

\begin{tabular}{|c|c|c|c|c|c|c|c|c|c|c|}
\hline Equation & $\begin{array}{c}1 \\
(\mathrm{OLS})\end{array}$ & $\begin{array}{c}2 \\
(\mathrm{OLS})\end{array}$ & $\begin{array}{c}3 \\
(\mathrm{FE})\end{array}$ & $\begin{array}{c}4 \\
(\mathrm{FE})\end{array}$ & $\begin{array}{c}5 \\
(\mathrm{FE})\end{array}$ & $\begin{array}{c}6 \\
(\mathrm{FE})\end{array}$ & $\begin{array}{c}7 \\
(\mathrm{FE})\end{array}$ & $\begin{array}{c}8 \\
(\mathrm{FE})\end{array}$ & $\begin{array}{c}9 \\
(\mathrm{FE})\end{array}$ & $\begin{array}{c}10 \\
(\mathrm{FE})\end{array}$ \\
\hline Constant & $\begin{array}{l}-16.09 * * \\
(1.43)\end{array}$ & $\begin{array}{l}-16.75^{* *} \\
(2.53)\end{array}$ & $\begin{array}{l}92.87 * * \\
(2.03)\end{array}$ & $\begin{array}{l}7.20 \\
(0.26)\end{array}$ & $\begin{array}{l}95.38 * \\
(1.68)\end{array}$ & $\begin{array}{c}6.86 \\
(0.24)\end{array}$ & $\begin{array}{l}37.13 \\
(0.64)\end{array}$ & $\begin{array}{l}60.84 \\
(1.41)\end{array}$ & $\begin{array}{l}105.0^{* *} \\
(2.15)\end{array}$ & $\begin{array}{l}31.71 \\
(0.87)\end{array}$ \\
\hline $\begin{array}{l}\text { Initial level of } \\
\text { GDP per capita }\end{array}$ & $\begin{array}{l}-0.81 * * \\
(2.41)\end{array}$ & $\begin{array}{l}-0.80 * * * \\
(3.05)\end{array}$ & $\begin{array}{l}-10.5 * * * \\
(5.47)\end{array}$ & $\begin{array}{l}-6.33^{* * *} \\
(4.00)\end{array}$ & $\begin{array}{l}-9.79 * * * \\
(4.34)\end{array}$ & $\begin{array}{l}-6.06 * * * \\
(4.47)\end{array}$ & $\begin{array}{l}-10.3 * * * \\
(4.64)\end{array}$ & $\begin{array}{l}-10.1 * * * \\
(4.67)\end{array}$ & $\begin{array}{l}-12.0 * * * \\
(5.41)\end{array}$ & $\begin{array}{l}*-8.05 * * * \\
(2.95)\end{array}$ \\
\hline Population growth & $\begin{array}{l}-0.26 \\
(1.04)\end{array}$ & $\begin{array}{l}-0.78 * * * \\
(4.30)\end{array}$ & $\begin{array}{l}-0.30 \\
(0.08)\end{array}$ & $\begin{array}{c}0.36 \\
(1.14)\end{array}$ & $\begin{array}{l}-0.51 \\
(0.86)\end{array}$ & $\begin{array}{l}0.19 \\
(0.52)\end{array}$ & $\begin{array}{l}-0.30 \\
(0.58)\end{array}$ & $\begin{array}{c}0.47 \\
(1.00)\end{array}$ & $\begin{array}{l}-0.26 \\
(0.62)\end{array}$ & $\begin{array}{c}0.60 \\
(1.53)\end{array}$ \\
\hline $\begin{array}{l}\text { Government } \\
\text { consumption }\end{array}$ & $\begin{array}{l}-0.11 * * * \\
(2.64)\end{array}$ & $\begin{array}{l}-0.37 \\
(1.16)\end{array}$ & $\begin{array}{l}-0.21 * * \\
(2.51)\end{array}$ & $\begin{array}{l}-0.12^{*} \\
(1.79)\end{array}$ & $\begin{array}{l}-0.26 \\
(1.39)\end{array}$ & $\begin{array}{l}0.17 \\
(1.50)\end{array}$ & $\begin{array}{l}-0.11 \\
(1.11)\end{array}$ & $\begin{array}{l}-0.99 \\
(0.86)\end{array}$ & $\begin{array}{l}-0.23 * * * \\
(2.62)\end{array}$ & $\begin{array}{c}* 0.18 * * \\
(2.40)\end{array}$ \\
\hline $\begin{array}{l}\text { Secondary } \\
\text { education }\end{array}$ & $\begin{array}{l}-0.36 \\
(0.24)\end{array}$ & $\begin{array}{l}-0.10 \\
(0.09)\end{array}$ & $\begin{array}{l}0.10^{* * * *} \\
(2.82)\end{array}$ & $\begin{array}{c}0.41 \\
(1.44)\end{array}$ & $\begin{array}{l}0.16^{* *} \\
(2.40)\end{array}$ & $\begin{array}{r}0.91^{*} \\
(1.96)\end{array}$ & $\begin{array}{l}0.10 * * \\
(2.09)\end{array}$ & $\begin{array}{l}0.12 * * \\
(2.33)\end{array}$ & $\begin{array}{l}0.11 * * * \\
(2.71)\end{array}$ & $\begin{array}{l}0.81 * * \\
(2.15)\end{array}$ \\
\hline Life expectancy & $\begin{array}{r}3.75^{*} \\
(1.65)\end{array}$ & $\begin{array}{l}4.75 * * * \\
(2.67)\end{array}$ & $\begin{array}{l}-8.52 \\
(0.93)\end{array}$ & $\begin{array}{c}6.82 \\
(1.43)\end{array}$ & $\begin{array}{l}-10.05 \\
(0.80)\end{array}$ & $\begin{array}{l}5.08 \\
(0.91)\end{array}$ & $\begin{array}{l}2.24 \\
(0.18)\end{array}$ & $\begin{array}{l}-2.58 \\
(0.32)\end{array}$ & $\begin{array}{l}-8.78 \\
(0.92)\end{array}$ & $\begin{array}{l}3.70 \\
(0.69)\end{array}$ \\
\hline Investment & $\begin{array}{l}0.25 * * * \\
(8.12)\end{array}$ & $\begin{array}{l}0.18 * * * \\
(7.30)\end{array}$ & $\begin{array}{l}0.35 * * * \\
(7.30)\end{array}$ & $\begin{array}{l}0.18^{* * * *} \\
(4.07)\end{array}$ & $\begin{array}{l}0.36^{* * * *} \\
(5.21)\end{array}$ & $\begin{array}{l}0.16^{* * * *} \\
(3.03)\end{array}$ & $\begin{array}{l}0.35 * * * \\
(6.04)\end{array}$ & $\begin{array}{l}0.34 * * * \\
(5.55)\end{array}$ & $\begin{array}{l}0.34 * * * \\
(7.52)\end{array}$ & $\begin{array}{l}0.25^{* * *} \\
(4.94)\end{array}$ \\
\hline $\begin{array}{l}\text { Economic freedom of } \\
\text { the world index (EFW) }\end{array}$ & $\begin{array}{l}0.86^{* * * *} \\
(3.09)\end{array}$ & $\begin{array}{l}0.46^{* *} \\
(2.24)\end{array}$ & $\begin{array}{l}1.53 * * * \\
(2.03)\end{array}$ & $\begin{array}{l}1.06^{* * *} \\
(2.62)\end{array}$ & $\begin{array}{l}1.56 \\
(1.47)\end{array}$ & $\begin{array}{l}1.93 * * \\
(2.23)\end{array}$ & $\begin{array}{l}2.60 * * * \\
(2.30)\end{array}$ & $\begin{array}{r}1.36^{*} \\
(1.68)\end{array}$ & $\begin{array}{l}1.44 * * * \\
(3.23)\end{array}$ & $\begin{array}{c}0.47 \\
(1.40)\end{array}$ \\
\hline Inflation & $\begin{array}{l}-0.76 \\
(1.42)\end{array}$ & $\begin{array}{l}-0.12 * * * \\
(3.80)\end{array}$ & $\begin{array}{l}-0.12 * * \\
(2.07)\end{array}$ & $\begin{array}{l}-0.13 * * * \\
(3.91)\end{array}$ & $\begin{array}{l}-0.35 \\
(1.17)\end{array}$ & $\begin{array}{l}-0.66 \\
(0.03)\end{array}$ & $\begin{array}{l}-0.56 \\
(0.52)\end{array}$ & $\begin{array}{l}-0.12 * * * \\
(3.14)\end{array}$ & $\begin{array}{l}-0.97 * \\
(1.73)\end{array}$ & $\begin{array}{l}-0.12 * * * \\
(3.37)\end{array}$ \\
\hline Aid (ODA) & -- & $\begin{array}{c}0.42 \\
(0.24)\end{array}$ & -- & $\begin{array}{l}0.84 * * \\
(2.53)\end{array}$ & -- & $\begin{array}{c}1.13 \\
(1.13)\end{array}$ & -- & $\begin{array}{l}0.93 * * \\
(1.99)\end{array}$ & -- & $\begin{array}{c}0.15 \\
(0.50)\end{array}$ \\
\hline Aid (ODA) x EFW & -- & $\begin{array}{l}0.36 \\
(0.01)\end{array}$ & -- & $\begin{array}{l}-0.79^{*} \\
(1.79)\end{array}$ & -- & $\begin{array}{l}-0.81 \\
(0.56)\end{array}$ & -- & $\begin{array}{l}-0.19 * * * \\
(2.92)\end{array}$ & -- & -- \\
\hline $\operatorname{Aid}^{2}(\mathrm{ODA})$ & -- & $\begin{array}{l}-0.17 \\
(0.90)\end{array}$ & -- & $\begin{array}{l}-0.25 * * * \\
(3.16)\end{array}$ & - & $\begin{array}{l}-0.43 * * \\
(2.50)\end{array}$ & -- & $\begin{array}{l}-0.19^{* *} \\
(2.18)\end{array}$ & -- & $\begin{array}{l}-0.20 * * * \\
(0.97)\end{array}$ \\
\hline Aid (EDA) & $\begin{array}{c}0.43 \\
(1.62)\end{array}$ & -- & $\begin{array}{c}0.32 \\
(0.72)\end{array}$ & -- & $\begin{array}{c}1.42 \\
(0.86)\end{array}$ & -- & $\begin{array}{l}1.34 * * \\
(2.16)\end{array}$ & -- & $\begin{array}{l}-0.17 \\
(0.69)\end{array}$ & -- \\
\hline Aid (EDA) $x$ EFW & $\begin{array}{l}-0.72 \\
(1.60)\end{array}$ & -- & $\begin{array}{l}-0.66 \\
(0.87)\end{array}$ & -- & $\begin{array}{l}-0.22 \\
(0.82)\end{array}$ & -- & $\begin{array}{l}-0.23 * * \\
(1.98)\end{array}$ & -- & -- & -- \\
\hline $\operatorname{Aid}^{2}(\mathrm{EDA})$ & $\begin{array}{l}-0.90 * * \\
(2.25)\end{array}$ & -- & $\begin{array}{l}-0.39 * * * \\
(3.93)\end{array}$ & -- & $\begin{array}{l}-0.65 * * * \\
(3.00)\end{array}$ & $=-$ & $\begin{array}{l}-0.30 * * \\
(2.60)\end{array}$ & -- & $\begin{array}{l}-0.34 * * * \\
(3.57)\end{array}$ & * -- \\
\hline Adjusted $\mathrm{R}^{2}$ & $\begin{array}{l}235 \\
0.36\end{array}$ & $\begin{array}{l}328 \\
0.35\end{array}$ & $\begin{array}{l}235 \\
0.65\end{array}$ & $\begin{array}{l}328 \\
0.58\end{array}$ & $\begin{array}{l}146 \\
0.63\end{array}$ & $\begin{array}{l}219 \\
0.55\end{array}$ & $\begin{array}{l}174 \\
0.65\end{array}$ & $\begin{array}{l}214 \\
0.57\end{array}$ & $\begin{array}{l}221 \\
0.66\end{array}$ & $\begin{array}{l}278 \\
0.59\end{array}$ \\
\hline
\end{tabular}

Notes: Equations (1), (2): OLS without group dummy variables. Equations (3) - (10): 2SLS Fixed effects (FE) model with group dummy variables and period effects. Absolute t-values in brackets. *** (**,*) denotes significance at the $1 \%(5 \%, 10 \%)$ level. Instruments for aid: (i) Level of income at the beginning of each period (ii) Population (iii) Infant mortality (iv) Illiteracy rate. 
restriction was set for initial income. Countries considered had to have an initial income of less than $\$ 2,200$ per capita. Since the range of income in the sample varied widely, this restriction was created to ensure that the sample contained countries in approximately the same development phase. Finally, regressions (9) and (10) removed the restrictions on the economic freedom of the world variable, but doubled the income allowed in the sample. The new limit was set to an annual income of $\$ 4,400$ per capita, above which countries were not considered.

Compared to OLS, using fixed effect modeling significantly boosted the explanatory power of the model - adjusted $\mathrm{R}^{2}$ now ranging from 55 to $66 \%$. Initial level of GDP per capita and investment were consistently very important in explaining economic growth, with economic freedom of the world index and secondary education not far behind in importance. Government consumption, depending on the regression, was occasionally significant, and negative.

The effect of aid on growth can be calculated by taking a partial derivative with respect to aid of the equation:

$(\text { growth })_{\mathrm{it}}=\alpha+\gamma^{\prime}(\text { control })_{\mathrm{it}}+\beta_{1}^{\prime}(\text { aid })_{\mathrm{it}}+\beta_{2}{ }^{\prime}\left(\text { aid }^{*} \text { policy }\right)_{\mathrm{it}}+\beta_{3}^{\prime}\left(\text { aid }^{2}\right)_{\mathrm{it}}+\varepsilon_{\mathrm{it}}$

This yields

$\delta($ growth $) / \delta($ aid $)=\beta_{1}+\beta_{2} *($ policy $)+2 \beta_{3} *($ aid $)$

Substituting significant coefficients and sample averages to the partial derivative equation above yields an average of -3.65 for fixed effect regressions (3) - (10), the range being from -6.11 to -2.56 . What this means is that on average a $1 \%$ increase in aid as a percentage of GDP in the sample decreases annual real GDP per capita growth by $3.65 \% .{ }^{14}$ Thus, the

\footnotetext{
${ }^{14}$ The $90 \%$ confidence interval for this result was from -24.2 to +7.75 . Even though initial GDP per capita was used to control for the fact that aid may flow to countries of poorest economic performance, additional tests were
} 
finding indicates that decreasing the level of development aid may actually have a beneficial effect on growth. In terms of sample averages this finding means that increasing per capita aid by $\$ 295$ decreases the average per capita income from $\$ 2,949$ to $\$ 2,875$. As described in an earlier section of this paper, one can try to explain this in various ways.

For instance, if new aid is likely to flow to countries of poor economic performance, aid-dependency, a disincentive to self-improvement, may be created. Supposing that the alternatives for a recipient nation are: a) to get free aid if no extra economic effort is made, or b) to get no aid if extra economic effort is made, then rational individuals and governments may in some circumstances well decide to forgo the extra effort option. If option a) is accepted, and the aid is allocated into inefficient uses - perhaps because of a corrupt recipient government, or because the donor has restricted (tied) the free use of the aid - then it is possible that the recipient nation would be worse off with the outside help. This logic is reminiscent of that by Devarajan, Dollar \& Holmgren (eds.) (2001), Vasquez (1998) and Kornai (1992) mentioned earlier.

Furthermore, contrary to the results of Burnside \& Dollar (2000), it seems to matter very little in terms of economic growth whether aid is given to countries with good governance, institutions and policies, or not. Even though it seems plausible that aid given to countries of good governance would yield better results than aid given to countries of poor governance, dropping the aid interacted with governance variable actually marginally boosted the explanatory power - as measured by adjusted $\mathrm{R}^{2}$ - of the model.

Interestingly, in the three of the ten cases when the aid interacted with governance term was actually statistically significant, it always had a negative sign. One possible

also performed. The results from Granger causality tests, with both one and two period lags, were inconclusive, though. 
explanation for the finding could be that donors may feel more free to attach strings to aid to countries with good governance then to countries with poor governance, i.e., stipulations are more likely to be attached and enforced when donors feel a higher level of confidence that the stipulations will be followed by the recipient. Again, if these stipulations redirect recipient's scarce resources into relatively inefficient uses, economic growth could be negatively affected.

Finally, the use of alternative aid datasets - EDA, ODA - yielded essentially the same results. This is hardly surprising since the correlation coefficient between these sets was very close to one for comparable sets. Even though EDA by construction probably ought to be the preferred choice in aid regressions, the closeness of the results also means that the results from aid studies before 1998 and the EDA dataset may still be reasonably comparable to results from newer studies that use EDA.

\subsection{Conclusion}

This study looked at the effect of development aid on economic growth for the years 19751998. The sample covered up to 86 developing countries, used two alternative datasets for aid, and compared to previous studies of aid effectiveness, a more advanced measure of the quality of governance.

Contrary to some previous findings in the development aid literature, the results from the fixed effect model with group dummy variables and period effects indicated a negative relationship between development aid and economic growth. In particular, it was found that a $1 \%$ increase in aid as a $\%$ of GDP decreased annual real GDP per capita growth by $3.65 \%$. 
Furthermore, aid given to countries with a better quality of governance was not found to improve the effectiveness of aid, contrary to the suggestion in Burnside \& Dollar (2000). In this study it was suggested that these results may emanate from the negative effects of aid on work effort, and from the stipulated end uses of aid, that may lead to misallocation of scarce resources in the recipient country.

Overall, the results of this study do not provide support for the notion that international development aid - at least as in practice between 1975 and 1998 - helps developing countries to higher growth trajectories. The study also pointed out that the level of governance as measured by the economic freedom of the world index was a considerable factor in explaining growth in the sample. This was not the case when it was coupled with development aid. Thus, the current role of western governments is not easily justifiable if the objective of aid disbursement is to foster economic growth. This does not, of course, exclude any other rationale that may be behind development aid, such as providing humanitarian aid in case of emergencies. However, if the objective of development aid is to foster growth, the current donor governments may be well advised, as the importance of the economic freedom index in the regressions suggested, to move their development policy focus from cash grants to programs that help to create sound institutional environments in recipient countries. That is, helping and encouraging developing countries to create business environments that are compatible with free markets is a promising and a potentially cost-effective way to unleash the individual effort and creativity in those countries.

The next chapter considers what governments can do to spur the above mentioned individual effort and creativity. In particular, the chapter analyzes the kind of government 
created policies and institutions that have been the most helpful in providing incentives for entrepreneurial activity in selected transition economies. 


\section{ENTREPRENEURSHIP IN POST-SOCIALIST ECONOMIES ${ }^{15}$}

Following the disintegration of the Soviet Union in December 1991, the former Soviet republics and many other Eastern European nations were free to begin their full-fledged transition from socialism to capitalism. Private sector entrepreneurship, an activity that had generally been illegal for decades under the socialist systems, suddenly became not only legal, but also essential for the creation of wealth and economic progress in these countries. As is pointed out by Havrylyshyn (2001), over the past decade these post-socialist transition economies have followed somewhat different courses, based on different institutional reforms, and the degree of success has varied widely across these countries. ${ }^{16}$ While there are many ways in which one could assess the success of the transitional countries, this paper focuses on exploring and explaining the differences in their ability to generate and foster continuing private-sector entrepreneurship.

\subsection{Introduction to entrepreneurship in transition economies}

The basis for our focus on entrepreneurship, rather than other measures of transitional success, is that entrepreneurship is increasingly becoming recognized in the academic literature as a key factor contributing to economic growth. As is argued by Minniti (1999), entrepreneurs are the catalysts for economic growth because they create a networking externality that promotes the creation of new ideas and new market formations. Baumol (1968) states that the central question faced by every market economy is how to encourage entrepreneurial activity. Schumpeter $(1934,1942)$ states that the key to the success of markets

\footnotetext{
${ }^{15}$ This chapter is based on: Ovaska \& Sobel (2003): “Entrepreneurship in post-socialist economies,' mimeo, West Virginia University, Morgantown, WV.

${ }^{16}$ For additional evidence on the varied degree of success among these countries, see Campos and Coricelli (2002).
} 
lies in the spirits of entrepreneurs who persist in developing new products and technologies, and succeed at ultimately reducing production costs. Kirzner (1997) argues that the entrepreneurial discovery process is vital to the effectiveness of markets. Whether entrepreneurs are "catalysts for economic growth," "the key to the success of markets," or are simply "vital to the effectiveness of markets," the point is clear - entrepreneurship is important for a healthy, well-functioning market economy.

Acs (2003) provides a good intuitive explanation of the importance of entrepreneurial start-ups for economic development. As he notes, the static view of industrial organization has traditionally argued that small firms are sub-optimal in terms of economic efficiency since they by their nature are unable to reap the full benefits of scale economies. Accordingly, this would at first sight seem to result in welfare outcome inferior to that from larger firms that, thanks to their size, can produce goods and services at lower unit costs. However, this is not correct, for two reasons. First, small firms also act as a countervailing power in the markets, forcing the larger business units to act more competitively. Thus, small firms help to restore the equilibrium price and quantity to competitive levels, in effect reducing the potential misuse of market power by large enterprises. Second, the potential to create new enterprises can alleviate the problems associated with unclear property rights in larger companies. Generally, when an employee of a large company comes up with a new innovation, the copyright of that innovation becomes the property of the company. In this case, the inventor may not be appropriately rewarded for his accomplishment. In fact, the shareholders of the company would be the main beneficiaries of the new invention. Then, this incentive set-up may stifle the rate of innovation in larger companies. But, by creating his own company the innovator can by-pass this problem of free riders, and collect the benefits of his own invention 
to a larger extent. Not surprisingly then, entrepreneurial start-ups are often characterized by high rate of new knowledge formation.

Empirically, the finding that increased entrepreneurial activity leads to greater economic growth has been well founded at both the national and local levels. For example, Reynolds, Hay, and Camp (1999) show that one-third of the differences in national economic growth rates can be attributed to different rates of entrepreneurship. Supporting these findings, Zacharakis, Bygrave, and Sheperd (2000) study sixteen developed economies and find that entrepreneurial activity explains approximately one-half of the differences in GDP growth between countries. More recently, Henderson (2002) argues that entrepreneurs significantly impact economic activity at a more local level through fostering localized job creation, increasing wealth and local incomes, and connecting local economies to the larger, global economy. Berkowitz \& DeJong (2001) find that entrepreneurial activity is an important factor in fostering economic growth and job creation. Specifically focusing on Russia, they find that regional economic growth within Russia is closely tied to the prevalence of entrepreneurial activity.

Undoubtedly, entrepreneurial risk taking leads to new and improved products, wealth creation, and ultimately, helps societies to improve their allocation of scarce resources. As is stated by McMillan \& Woodruff (2002), this is particularly relevant in the context of postsocialist economies where entrepreneurs can potentially facilitate these economies' ongoing transition process. This paper examines the rates of entrepreneurial activity in these postsocialist economies, and an attempt is made to uncover the policies and institutions that appear to be the most highly correlated with a country's success (or failure) in promoting this 
activity. ${ }^{17}$ The sample consists of ten Baltic and Central-European economies that generally started their transition process in the early 1990s. ${ }^{18}$

\subsection{Transitional Success and Entrepreneurship}

There are many ways to assess the degree of 'success' in the transitional post-socialist economies, with each measure having its own distinct advantages and disadvantages. Table 4.1. presents data for several key economic indicators that might be used to measure the degree to which these economies have obtained success in fostering economic growth and progress. The period beginning in 1995 is chosen for three reasons. first, the period before this (during the first few years of transition) was characterized by a huge degree of uncertainty in these economies leading to rather large year-to-year variations in all economic measures. Second, the amount and reliability of the data available for these economies is vastly improved beginning in mid ' 90 s. The third and final reason is because the rates of entrepreneurship in this later period were likely more reflective of the long-term sustainable rates of entrepreneurial activity that the policies of these countries will foster.

The measures presented in Table 4.1. are, GDP per capita (both the 2000 level and the average annual growth rate from 1995-2000), the private sector as a share of GDP in 2000, the number of active private enterprises per 1,000 population in 1995 , and the average annual growth rates of both private enterprises and patent and trademark applications per capita from 1995-2000. As is measured by GDP per capita, the countries that have achieved the highest living standards for their citizens by 2000 were Slovenia, the Czech Republic, Hungary, the

\footnotetext{
${ }^{17}$ OECD (1998), Chapter 13, contains a detailed account of the difficulties and barriers to fostering entrepreneurial activity in post-socialist economies. Pfirrmann and Walter (2002) contains a set of articles discussing specific issues with regard to entrepreneurial activity in some of the transition economies.

${ }^{18}$ Estonia, Latvia, Lithuania, Poland, Czech Republic, Slovak Republic, Hungary, Romania, Bulgaria and Slovenia.
} 
Slovak Republic, and Estonia. The countries with the lowest living standards were Bulgaria,

Romania, Latvia, and Lithuania. The difference between the two groupings is substantial, in most cases by at least a factor of two. While a 'convergence' theory might predict that those countries with the lowest levels of GDP per capita would experience the fastest growth, this is not witnessed in the data. In fact, the countries with the highest GDP per capita are also those with the fastest growth rates of GDP per capita. This is precisely because it is the policies that foster high living standards as measured by the level of per capita GDP that also foster faster rates of economic growth. Policies that tend to retard economic growth also tend to lead

\section{Table 4.1. Selected Economic \& Entrepreneurship Data for the Transition Economies}

\begin{tabular}{|c|c|c|c|c|c|c|c|}
\hline & \multirow[b]{2}{*}{$\begin{array}{c}\text { Start of } \\
\text { Transition }\end{array}$} & \multicolumn{2}{|c|}{ GDP per capita } & \multirow[b]{2}{*}{$\begin{array}{l}\text { Private } \\
\text { Sector } \\
\text { Share of } \\
\text { GDP in } \\
2000\end{array}$} & \multirow[b]{2}{*}{$\begin{array}{c}\text { Active } \\
\text { Enterprises } \\
\text { per } 1,000 \\
\text { People in } \\
1995 \\
\end{array}$} & \multirow[b]{2}{*}{$\begin{array}{l}\text { Avg. Annual } \\
\text { Number of New } \\
\text { Enterprises per } \\
\text { 1,000 People } \\
1995-2000\end{array}$} & \multirow{2}{*}{$\begin{array}{l}\text { Avg. Annual } \\
\text { Patent and } \\
\text { Trademark } \\
\text { Applications } \\
\text { per 1,000 } \\
\text { People } \\
1995-2000 \\
\end{array}$} \\
\hline & & $\begin{array}{c}\text { PPP } \\
\text { dollars } \\
\text { in } 2000\end{array}$ & $\begin{array}{l}\text { Avg. Annual } \\
\text { Percent } \\
\text { Growth } \\
1995-2000 \\
\end{array}$ & & & & \\
\hline Bulgaria & Jan 1990 & $\$ 5,710$ & $0.1 \%$ & $70 \%$ & 40.6 & 7.9 & 0.37 \\
\hline Czech Rep. & Dec 1989 & 13,991 & 1.9 & 80 & 69.0 & 9.3 & 0.76 \\
\hline Estonia & Dec 1991 & 10,066 & 6.4 & 75 & 20.0 & 3.6 & 0.48 \\
\hline Hungary & Sep 1989 & 12,416 & 4.0 & 80 & 54.7 & 5.9 & 0.42 \\
\hline Latvia & Sep 1991 & 7,045 & 5.0 & 65 & 10.9 & 2.0 & 0.46 \\
\hline Lithuania & Sep 1991 & 7,106 & 3.5 & 70 & 18.7 & 2.7 & 0.50 \\
\hline Poland & Jul 1989 & 9,051 & 5.4 & 70 & 36.6 & 5.8 & 0.35 \\
\hline Romania & Dec 1989 & 6,423 & 0.1 & 60 & 17.1 & 2.7 & 0.22 \\
\hline Slovak Rep. & Dec 1989 & 11,243 & 4.4 & 80 & 42.5 & 5.5 & 0.37 \\
\hline Slovenia & Jun 1991 & 17,367 & 4.3 & 65 & 35.6 & 3.6 & 0.56 \\
\hline Average & & 10,042 & 3.5 & 72 & 34.6 & 4.9 & 0.45 \\
\hline
\end{tabular}

Sources: Eurostat 2002, World Development Indicators 2002, WIPO, Transition Report 1999, 2002

Notes: The surveys on which the above enterprise estimates are based covered registrations of non-agricultural enterprises on the business registers of each country during the corresponding time periods. Public administration and private non-profit enterprises were excluded. True creation excludes agricultural, public administration and private non-profit enterprises as well as enterprises that were reregistered because of privatization or co-operative split. 
to lower overall standards of living. Some countries such as Bulgaria and Romania have experienced particularly low rates of economic growth when compared to the other transitional economies.

As a share of the economy, the private sectors of the Czech Republic, Hungary, and the Slovak Republic are the largest, all around 80 percent of GDP, while Romania, Latvia, and Slovenia have the smallest private sectors, all around 60 to 65 percent of GDP. On average, these transition economies tend to have private sectors averaging 72 percent of GDP, approximately the same as most developed Western nations. The countries with the highest initial level of active private enterprises per capita in 1995 were the Czech Republic, Hungary, the Slovak Republic, and Bulgaria, while Latvia, Romania, and Lithuania lagged far behind.

The final two columns show the two best measures of entrepreneurial activity available for these economies, the number of new enterprises and the number of new patent and trademark applications. While both attempt to measure entrepreneurial activity, they are clearly different. While it is true that the Czech Republic tops both lists, and that Romania is near the bottom of both lists, the data for the other countries is not so clearly related. Bulgaria, for example, has a very respectable rate of new enterprise creation, but has one of the lowest rates of patent and trademark applications. This difference is reflected in the relatively low 0.365 simple correlation coefficient between these two measures of entrepreneurial activity. Of the two measures, patent activity has the highest simple correlation coefficients with both GDP per capita and the average growth rate of GDP per capita, reflecting that it is perhaps the measure of entrepreneurship that is most highly associated with economic growth and wealth creation. It is contended, for the purposes of this study, that new enterprise creation tends to 
measure the start up of all new businesses (including small retail shops), while patent and trademark activity is more reflective of high-tech entrepreneurial innovation that is generally undertaken by larger, existing firms. Nonetheless, the data presented in Table 4.1. show that the countries that tend to have the highest economic growth rates, and the highest levels of GDP per capita, are precisely those that tend to have higher rates of entrepreneurship, by one or both of the measures.

The data presented in this section shows that there is a great deal of variation in the success of these transitional economies in fostering private-sector entrepreneurial activity. In addition, there appears to be a close relationship between the overall progress made by these countries and their rates of entrepreneurial activity. In the next section attention is turned to estimating a model to uncover the factors most highly correlated with the degree of entrepreneurial activity in these countries.

\subsection{The model and empirical results}

What are the determinants of entrepreneurial activity? ${ }^{19}$ In the words of Leibenstein (1968), the critical element for the existence or absence of entrepreneurial activity is whether proper motivations - promise of profits - are in place. Previous literature, as summarized by OECD (1998) and Havrylyshyn (2001), hints towards several factors including the availability of credit and venture capital, solid and unbiased laws, well-define private property rights, and 'good' political and economic institutions, that lead to greater entrepreneurial activity.

In this section the determinants of entrepreneurial activity in these countries for the period 1995-2000 using a panel random effects model with both group and period effects are

\footnotetext{
${ }^{19}$ Earle \& Sakova (1999) explore the factors associated with individual decisions to be self-employed in postcommunist Eastern Europe. Here we explore the factors associated with different levels of overall rates of entrepreneurial activity in these countries.
} 
examined. The data employed is annual data, and the descriptions and sources for our data are listed in Appendix C. The dependent variables used to measure entrepreneurial activity are presented in Table 4.1. (both new enterprise creation and patent and trademark applications). Explanatory variables include variables reflecting many of the factors listed above. GDP per capita is included to control for the impact of initial wealth on entrepreneurial activity. However, because of the possibility of endogeneity (higher entrepreneurial activity creating a larger GDP per capita), regressions are also shown with this variable excluded. If anything, this variable is expected to be positively correlated with entrepreneurial activity. In addition, an index that measures of the quality of government-provided infrastructure (including telecommunications, electric power, railways, roads, water, and waste) is included. If government investment in infrastructure is important in fostering entrepreneurial activity, this variable should have a positive coefficient. Another measure in regressions, domestic loan availability (loans as a percent of GDP), should have a positive coefficient if loan availability is a significant factor affecting entrepreneurial activity. Non-performing loans (as a percent of total loans) are included to measure the degree to which firms can count on receiving payment for the goods and services they provide. As a measure of contract enforcement, this variable is predicted to have a negative coefficient. However, it is also possible that this variable reflects business failures, and the correspondingly higher rate of interest that banks must charge on all loans. Again, however, this effect would tend to show up as a negative coefficient.

The next two variables are intended to reflect the soundness of governmental institutions and policies in these countries. An index of government corruption is included, and this variable is expected to be negatively correlated with entrepreneurial activity. The index of economic freedom is an index that incorporates many variables measuring such 
factors as sound legal institutions, secure property rights, low taxes, and low regulations. ${ }^{20}$ This variable is expected to have a positive coefficient suggesting that more economic freedom leads to greater levels of entrepreneurial activity. Three additional variables are included in most specifications of the regression models. The first of these is net foreign direct investment as a share of GDP, which is also a measure of financial capital availability, and is expected to have a positive coefficient. Import tariffs as a percent of GDP are included to see whether domestic protectionist policies tend to foster entrepreneurial activity in a country. While this is inconsistent with standard economic theory suggesting that tariffs are harmful to an economy, some of these economies have employed restrictive tariffs as an attempt to foster domestic industry. Finally, the inflation rate is incorporated to reflect the soundness of monetary policy in the country. It is expected, if anything, to be negatively related to entrepreneurial activity. Tables 4.2. and 4.3. present the results of our regression analysis for these two different measures of entrepreneurial activity.

The first thing that is clear looking at the two tables is that the results are very robust to the addition or subtraction of other variables from the regression (with a few exceptions that will be discussed). ${ }^{21}$ This is true for both tables. The second thing that is immediately apparent is that the set of variables that tends to be the most significant in explaining new enterprise creation in Table 4.2. is generally not the same as the set of variables that tends to be most significant in explaining patent and trademark activity in Table 4.3. Most likely this is because these two measures actually capture two distinct aspects of entrepreneurial activity.

\footnotetext{
${ }^{20}$ While the Gwartney, Lawson, et al (2002) Economic Freedom Index is more frequently used, we employ this one because the Gwartney, Lawson, et al index is only available at five-year intervals.

${ }^{21}$ Slovenia with its market socialist background was clearly different from the other countries in the sample. Whereas the other countries had had little exposure to the workings of the markets in the decades before transition, Slovenia's economic system was based on markets. Interestingly, though, the regression results were unchanged even if Slovenia was omitted from the sample. Thus, a head start on using markets does not necessarily seem to make a country markedly different from late-starters in terms of innovation rate.
} 
Table 4.2. Estimates of the 1995-2000 New Enterprise Creation Equations

Dependent variable: New Enterprises per 1,000 Inhabitants

\begin{tabular}{|c|c|c|c|c|c|c|c|c|}
\hline Sample & $\begin{array}{l}\text { All } \\
\text { Firms }\end{array}$ & $\begin{array}{l}\text { Small } \\
\text { Firms }\end{array}$ & $\begin{array}{l}\text { Large } \\
\text { Firms }\end{array}$ & $\begin{array}{l}\text { All } \\
\text { Firms }\end{array}$ & $\begin{array}{l}\text { All } \\
\text { Firms }\end{array}$ & $\begin{array}{l}\text { All } \\
\text { Firms }\end{array}$ & $\begin{array}{l}\text { All } \\
\text { Firms }\end{array}$ & $\begin{array}{l}\text { All } \\
\text { Firms }\end{array}$ \\
\hline Constant & $\begin{array}{r}9.87^{*} \\
(1.66)\end{array}$ & $\begin{array}{r}9.70^{*} \\
(1.65)\end{array}$ & $\begin{array}{r}0.18^{*} \\
(1.65)\end{array}$ & $\begin{array}{l}11.63^{*} \\
(1.90)\end{array}$ & $\begin{array}{l}7.56 \\
(1.35)\end{array}$ & $\begin{array}{l}6.10 \\
(1.20)\end{array}$ & $\begin{array}{l}9.97 * * * \\
(3.26)\end{array}$ & $\begin{array}{l}2.84 \\
(0.50)\end{array}$ \\
\hline $\begin{array}{l}\text { GDP per capita } \\
\text { (in constant \$) }\end{array}$ & $\begin{array}{l}-0.21 \\
(0.73)\end{array}$ & $\begin{array}{l}-0.21 \\
(1.06)\end{array}$ & $\begin{array}{c}0.49 \\
(0.10)\end{array}$ & -- & $\begin{array}{l}-0.25 \\
(0.91)\end{array}$ & $\begin{array}{l}-0.27 \\
(1.19)\end{array}$ & $\begin{array}{l}-0.18 \\
(0.65)\end{array}$ & $\begin{array}{l}-0.36 \\
(0.10)\end{array}$ \\
\hline $\begin{array}{l}\text { Infrastructure Reform } \\
\text { Index }\end{array}$ & $\begin{array}{l}-0.55 \\
(0.77)\end{array}$ & $\begin{array}{l}-0.55 \\
(0.78)\end{array}$ & $\begin{array}{l}-0.31 \\
(0.24)\end{array}$ & $\begin{array}{l}-0.65 \\
(0.90)\end{array}$ & $\begin{array}{l}-0.69 \\
(0.94)\end{array}$ & $\begin{array}{l}-0.53 \\
(0.76)\end{array}$ & $\begin{array}{l}-0.88 \\
(1.32)\end{array}$ & $\begin{array}{l}0.53 \\
(0.07)\end{array}$ \\
\hline $\begin{array}{l}\text { Credit Availability } \\
(\% \text { of loans of GDP) }\end{array}$ & $\begin{array}{l}0.84 * * \\
(2.41)\end{array}$ & $\begin{array}{l}0.85^{* *} \\
(2.47)\end{array}$ & $\begin{array}{l}-0.10 \\
(1.59)\end{array}$ & $\begin{array}{l}0.71 * * \\
(2.05)\end{array}$ & $\begin{array}{l}0.10^{* * * *} \\
(3.35)\end{array}$ & $\begin{array}{l}0.11 * * * \\
(3.93)\end{array}$ & $\begin{array}{l}0.90 * * * \\
(3.39)\end{array}$ & $\begin{array}{l}0.84 * * \\
(2.56)\end{array}$ \\
\hline $\begin{array}{l}\text { Non-performing } \\
\text { Loans (\% of total) }\end{array}$ & $\begin{array}{l}-0.41 \\
(1.45)\end{array}$ & $\begin{array}{l}-0.41 \\
(1.46)\end{array}$ & $\begin{array}{l}-0.11 \\
(0.21)\end{array}$ & $\begin{array}{l}-0.44 \\
(1.47)\end{array}$ & $\begin{array}{l}-0.38^{*} \\
(1.88)\end{array}$ & $\begin{array}{l}-0.38^{*} \\
(1.94)\end{array}$ & $\begin{array}{l}-0.37^{*} \\
(1.86)\end{array}$ & $\begin{array}{l}-0.28 \\
(1.30)\end{array}$ \\
\hline $\begin{array}{l}\text { Government } \\
\text { Corruption }\end{array}$ & $\begin{array}{l}-1.19 * * * \\
(2.61)\end{array}$ & $\begin{array}{l}-1.18 * * * \\
(2.60)\end{array}$ & $\begin{array}{l}-0.15^{*} \\
(1.73)\end{array}$ & $\begin{array}{l}-1.20 * * * \\
(2.64)\end{array}$ & $\begin{array}{l}-1.25 * * * \\
(2.79)\end{array}$ & $\begin{array}{l}-1.21 * * * \\
(2.87)\end{array}$ & $\begin{array}{l}-1.17^{* * * *} \\
(2.79)\end{array}$ & -- \\
\hline $\begin{array}{l}\text { Index of Economic } \\
\text { Freedom }\end{array}$ & $\begin{array}{c}0.19 \\
(0.12)\end{array}$ & $\begin{array}{l}0.17 \\
(0.11)\end{array}$ & $\begin{array}{c}0.16 \\
(0.53)\end{array}$ & $\begin{array}{l}0.79 \\
(0.46)\end{array}$ & $\begin{array}{l}-0.70 \\
(0.58)\end{array}$ & $\begin{array}{l}-0.98 \\
(0.87)\end{array}$ & -- & $\begin{array}{l}-0.16 \\
(0.12)\end{array}$ \\
\hline $\begin{array}{l}\text { Net Foreign Direct } \\
\text { Investment ( } \% \text { of GDP) }\end{array}$ & $\begin{array}{l}-0.24 \\
(0.32)\end{array}$ & $\begin{array}{l}-0.24 \\
(0.31)\end{array}$ & $\begin{array}{l}-0.96 \\
(0.67)\end{array}$ & $\begin{array}{l}-0.20 \\
(0.25)\end{array}$ & $\begin{array}{l}-0.11 \\
(0.15)\end{array}$ & -- & -- & -- \\
\hline $\begin{array}{l}\text { Import Tariffs } \\
(\% \text { of GDP) }\end{array}$ & $\begin{array}{c}0.11 \\
(0.61)\end{array}$ & $\begin{array}{c}0.11 \\
(0.63)\end{array}$ & $\begin{array}{l}-0.14 \\
(0.42)\end{array}$ & $\begin{array}{c}0.88 \\
(0.50)\end{array}$ & -- & -- & -- & -- \\
\hline Inflation Rate & $\begin{array}{l}-0.22^{*} \\
(1.66)\end{array}$ & $\begin{array}{l}-0.22^{*} \\
(1.73)\end{array}$ & $\begin{array}{l}-0.17 \\
(0.68)\end{array}$ & $\begin{array}{l}-0.23^{*} \\
(1.80)\end{array}$ & -- & -- & -- & -- \\
\hline Observations & 52 & 52 & 52 & 52 & 54 & 54 & 54 & 54 \\
\hline
\end{tabular}

Notes: Random effects model with group and period effects. Absolute t-statistics in parenthesis. ***,**** denotes significance at the 1\%,5\%, and 10\% levels respectively. Small [large] firm refers to newly created enterprises with 49 or less [50 or more] employees. 


\section{Table 4.3. Estimates of the 1995-2000 Patent and Trademark Applications Equations}

Dependent variable: Patent and Trademark Applications per 1,000 Inhabitants

\begin{tabular}{|c|c|c|c|c|c|c|c|c|c|c|}
\hline Equation & 1 & 2 & 3 & 4 & 5 & 6 & 7 & 8 & 9 & 10 \\
\hline Constant & $\begin{array}{r}0.76^{*} \\
(1.80)\end{array}$ & $\begin{array}{r}0.76^{*} \\
(1.83)\end{array}$ & $\begin{array}{r}0.61^{*} \\
(1.85)\end{array}$ & $\begin{array}{l}0.83 * * * \\
(2.60)\end{array}$ & $\begin{array}{l}0.96^{* * * *} \\
(2.99)\end{array}$ & $\begin{array}{r}0.89 * \\
(1.91)\end{array}$ & $\begin{array}{l}0.75 * * \\
(2.26)\end{array}$ & $\begin{array}{l}0.68 * * \\
(2.38)\end{array}$ & $\begin{array}{l}0.75 * * \\
(2.32)\end{array}$ & $\begin{array}{r}0.57 * \\
(1.83)\end{array}$ \\
\hline $\begin{array}{l}\text { GDP per capita } \\
\text { (in constant \$) }\end{array}$ & $\begin{array}{r}0.31^{*} \\
(1.74)\end{array}$ & $\begin{array}{r}0.31^{*} \\
(1.76)\end{array}$ & $\begin{array}{l}0.26^{* *} \\
(2.16)\end{array}$ & $\begin{array}{r}0.27 * \\
(1.65)\end{array}$ & $\begin{array}{l}0.35^{* *} \\
(2.07)\end{array}$ & -- & $\begin{array}{r}0.31^{*} \\
(1.76)\end{array}$ & $\begin{array}{r}0.27 * \\
(2.07)\end{array}$ & $\begin{array}{c}0.27 \\
(1.55)\end{array}$ & $\begin{array}{r}0.52 * \\
(1.68)\end{array}$ \\
\hline $\begin{array}{l}\text { Infrastructure Reform } \\
\text { Index }\end{array}$ & $\begin{array}{l}-0.19 \\
(0.04)\end{array}$ & $\begin{array}{l}-0.17 \\
(0.03)\end{array}$ & $\begin{array}{l}-0.49 \\
(0.11)\end{array}$ & $\begin{array}{l}-0.23 \\
(0.60)\end{array}$ & $\begin{array}{l}-0.32 \\
(0.80)\end{array}$ & $\begin{array}{c}0.22 \\
(0.97)\end{array}$ & -- & -- & -- & -- \\
\hline $\begin{array}{l}\text { Credit Availability } \\
(\% \text { of loans of GDP) }\end{array}$ & $\begin{array}{c}0.13 \\
(0.50)\end{array}$ & $\begin{array}{l}0.13 \\
(0.50)\end{array}$ & $\begin{array}{c}0.22 \\
(1.09)\end{array}$ & $\begin{array}{l}0.19 \\
(0.87)\end{array}$ & -- & $\begin{array}{c}0.28 \\
(1.04)\end{array}$ & $\begin{array}{c}0.13 \\
(0.50)\end{array}$ & $\begin{array}{c}0.16 \\
(0.73)\end{array}$ & $\begin{array}{l}0.19 \\
(0.76)\end{array}$ & $\begin{array}{l}0.13 \\
(0.54)\end{array}$ \\
\hline $\begin{array}{l}\text { Non-performing } \\
\text { Loans (\% of total) }\end{array}$ & $\begin{array}{c}0.43 \\
(0.20)\end{array}$ & $\begin{array}{c}0.44 \\
(0.21)\end{array}$ & $\begin{array}{l}-0.26 \\
(0.19)\end{array}$ & $\begin{array}{l}-0.36 \\
(0.25)\end{array}$ & -- & $\begin{array}{c}0.47 \\
(0.00)\end{array}$ & $\begin{array}{c}0.45 \\
(0.21)\end{array}$ & $\begin{array}{c}0.90 \\
(0.05)\end{array}$ & $\begin{array}{l}-0.87 \\
(0.04)\end{array}$ & -- \\
\hline $\begin{array}{l}\text { Government } \\
\text { Corruption }\end{array}$ & $\begin{array}{c}0.38 \\
(1.07)\end{array}$ & $\begin{array}{c}0.38 \\
(1.09)\end{array}$ & $\begin{array}{c}0.44 \\
(1.41)\end{array}$ & -- & -- & $\begin{array}{c}0.24 \\
(0.62)\end{array}$ & $\begin{array}{c}0.39 \\
(1.18)\end{array}$ & $\begin{array}{c}0.49 \\
(1.60)\end{array}$ & -- & -- \\
\hline $\begin{array}{l}\text { Index of Economic } \\
\text { Freedom }\end{array}$ & $\begin{array}{r}0.23 * \\
(1.91)\end{array}$ & $\begin{array}{l}0.23 * * \\
(1.97)\end{array}$ & $\begin{array}{l}0.17 * * \\
(2.30)\end{array}$ & $\begin{array}{l}0.18 * * \\
(2.19)\end{array}$ & $\begin{array}{l}0.21 * * \\
(2.36)\end{array}$ & $\begin{array}{r}0.23 * \\
(1.72)\end{array}$ & $\begin{array}{r}0.23^{*} \\
(1.96)\end{array}$ & $\begin{array}{l}0.21 * * \\
(2.09)\end{array}$ & $\begin{array}{r}0.18^{*} \\
(1.67)\end{array}$ & $\begin{array}{r}0.13^{*} \\
(1.67)\end{array}$ \\
\hline $\begin{array}{l}\text { Net Foreign Direct } \\
\text { Investment ( } \% \text { of GDP) }\end{array}$ & $\begin{array}{l}0.14 * * \\
(2.27)\end{array}$ & $\begin{array}{l}0.13 * * \\
(2.31)\end{array}$ & $\begin{array}{l}0.14 * * * \\
(2.72)\end{array}$ & $\begin{array}{l}0.13 * * \\
(2.47)\end{array}$ & $\begin{array}{l}0.99 * * \\
(2.06)\end{array}$ & $\begin{array}{l}0.13 * * \\
(2.02)\end{array}$ & $\begin{array}{l}0.13 * * \\
(2.29)\end{array}$ & $\begin{array}{l}0.14 * * \\
(2.53)\end{array}$ & $\begin{array}{l}0.12 * * \\
(2.11)\end{array}$ & $\begin{array}{l}0.11^{* *} \\
(2.27)\end{array}$ \\
\hline $\begin{array}{l}\text { Import Tariffs } \\
(\% \text { of GDP) }\end{array}$ & $\begin{array}{c}0.91 \\
(0.68)\end{array}$ & $\begin{array}{c}0.93 \\
(0.74)\end{array}$ & -- & -- & $\begin{array}{l}-0.85 \\
(0.11)\end{array}$ & $\begin{array}{c}0.10 \\
(0.72)\end{array}$ & $\begin{array}{c}0.92 \\
(0.70)\end{array}$ & $\begin{array}{c}0.73 \\
(0.62)\end{array}$ & $\begin{array}{c}0.64 \\
(0.53)\end{array}$ & -- \\
\hline Inflation Rate & $\begin{array}{c}0.25 \\
(0.02)\end{array}$ & -- & -- & -- & $\begin{array}{c}0.22 \\
(0.23)\end{array}$ & $\begin{array}{l}-0.14 \\
(0.01)\end{array}$ & $\begin{array}{c}0.20 \\
(0.02)\end{array}$ & -- & -- & -- \\
\hline Observations & 52 & 52 & 54 & 54 & 55 & 52 & 52 & 52 & 52 & 56 \\
\hline
\end{tabular}

Notes: Random effects model with group and period effects. Absolute t-statistics in parenthesis. ***, **,* denotes significance at the $1 \%, 5 \%$, and $10 \%$ levels respectively. 
As suggested earlier, new enterprise creation tends to measure the start up of all new businesses (including small retail shops), while patent and trademark activity is more reflective of high-tech entrepreneurial innovation that is generally undertaken by larger, existing firms. This line of reasoning would be supported by the fact presented in the discussion of Table 4.1. that patent and trademark activity is much more highly correlated with economic growth than is new enterprise creation.

From Table 4.2., the factors most significant in explaining new enterprise creation are credit availability, non-performing loans, government corruption, and inflation rates. Note that in the table, the first column shows our full regression using data reflecting the creation of all new firms. The following two columns show how these results change when the sample is restricted only to small firms and only to larger firms. The remaining columns simply show the robustness of the coefficient estimates to the inclusion and exclusion of some of the variables. Credit availability, while significant in almost all of the regressions appears to be much more significant in affecting the creation of small firms than large ones. This variable is insignificant in the regression that isolates only the determinants of large enterprise creation. Non-performing loans becomes significant only in the regressions that exclude inflation. When significant, it is of the expected sign, however. It is worth noting that in a survey of entrepreneurs, the results of which are presented in Eurostat (2002), they cited limited access to credit and non- or late-paying customers as two of the factors causing them the most difficulties. The results would support these reported claims.

The index of government corruption is highly significant, and negative, in all specifications. It is clear that a sound political process is essential to fostering new enterprise creation. However, government corruption it is more significant in hampering the creation 
rate of smaller firms than of larger ones. Larger firms are more likely to be able to use the political process to their advantage, so it is reasonable to expect that small firm creation is harmed to a greater extent by the presence of government corruption. Finally, the inflation rate is significant and negative in most of the regressions, with the exception of the one restricted to large firms. Again, this factor seems to be more important for small firms than for large ones.

Turning our attention to Table 4.3., and entirely different set of important explanatory variables emerges. GDP per capita is significant and positive in explaining the level of patent and trademark activity. Because this type of high-tech entrepreneurship requires a substantially greater degree of resources to undertake, this result sounds reasonable. However, even with this variable omitted, the same two additional variables are significant in the regression. The first of these is the index of economic freedom. This measure of sound government policy coupled with low taxes and regulations is highly significant and positively related to the level of patent and trademark activity. This result is consistent with similar empirical studies of entrepreneurship, such as Kreft \& Sobel (2003) who find that economic freedom is significant in explaining differences across U.S. states in the level of entrepreneurial activity. This finding is also consistent with the interpretation of what these two different measures of entrepreneurial activity reflect because it is fair to assume that higher tax rates and regulations (which are reflected in the economic freedom index) would have a larger impact on the willingness of individuals and companies to invest large sums of money in risky new technological innovations. ${ }^{22}$ The final significant variable is net foreign

\footnotetext{
${ }^{22}$ In addition, regressions were also run that included the private sector share in economy. Private sector share was insignificant when added as an extra variable to the main regression as well as when substituted for the index of economic freedom. This would seem to imply that the size of government alone is not necessarily
} 
direct investment, and it is also positive in the regression. It appears that countries can, to a certain extent, import this type of high-tech innovation from other countries through foreign direct investment.

Despite the fact that two different subsets of variables are significant when comparing the results from Tables 4.2. and 4.3., one of the most interesting findings is that there are two variables, government provided infrastructure and import tariffs, that are insignificant in both tables. Based on this one can conclude that protectionist tariffs can not, and do not, accomplish higher rates of domestic entrepreneurial activity. In addition, government provided infrastructure is not nearly as important as the other policies of government reflected in things such as less government corruption and higher levels of economic freedom (low taxes, low regulations, and secure private property rights). From a policy perspective, this clearly points to where government policy priorities should focus in these transitional economies.

Given the interpretation of these two measures - that new enterprise creation mostly reflects general private sector retail business activity, while patent and trademark activity reflects real technological innovation - the results suggest that the policies that foster one do not necessarily foster the other. Most important in fostering general business activity (especially among small businesses) are credit availability, sound monetary policy, and lack of government corruption. Most important in fostering real technological innovation are initial wealth levels, foreign direct investment, and policies consistent with economic freedom (low taxes and regulations and secure private property rights).

decisive for innovation rate. The correlation coefficient between the private sector share and the index of economic freedom was 0.60 . 
Despite the differences in these two measures, it is clear from a reexamination of the initial data presented in Table 4.1., that very successful transition countries such as Estonia tend to have all of the ingredients that are significant in both sets of regression results (low levels of government corruption, high economic freedom, high rates of foreign direct investment, high credit availability, low inflation, and good initial wealth). On the other hand, those countries on the lower end of the spectrum, such as Romania, tend to have few, if any, of these ingredients. Having policies consistent with fostering both types of entrepreneurial activity measured is highly correlated with economic success in these post-socialist transition economies.

\subsection{Conclusion}

The results clearly point to several key factors associated with high rates of entrepreneurial activity in post-socialist transition economies. These include credit availability, contract enforcement, low government corruption, sound monetary policy, high foreign direct investment, and policies (such as low regulations and taxes) that are consistent with giving citizens a high degree of economic freedom. It is found, however, that credit availability and government corruption tend to be more important factors affecting the creation rate of new smaller firms than for the creation rate of new larger firms.

Most importantly we find that there is no single set of variables most important in explaining our two different measures of entrepreneurial activity. In fact, it is found that different factors tend to be important in explaining new firm creation rates than the ones important in explaining patent and trademark activity. Factors such as a high rate of foreign direct investment, for example, are important in explaining patent and trademark activity but 
appear not to have much influence on new firm creation rates. On the other hand, credit availability, government corruption, and sound monetary policy are important in explaining new firm creation rates but appear not to have much influence on patent and trademark activity. Interestingly, though, some of these variables (such as government corruption) do not seem to hamper the new firm creation rate for large firms, only smaller ones. This result is logical because larger firms are generally in a better position to gain influence in a corrupt political system, while individuals starting small businesses are not. In addition, it is found that domestic import tariffs and government provided infrastructure do not seem to have a significant effect on entrepreneurial activity, regardless of how it is measured.

What the results suggest is that having policies that simply help the rate of new firm creation do not automatically also promote the high rates of technological innovation necessary for economic growth. Of the two measures, patent and trademark activity is more highly correlated with economic growth in these countries than is new firm creation. To be successful, these countries not only need to institute policies consistent with fostering the creation of new businesses but also have in place policies conducive with fostering new hightech innovation. One of the most important of these factors is the presence of economic freedom - low taxes, low regulations, and secure private property rights. As discussed in the first chapter of the dissertation, this finding provides further support to the idea of governments as enablers of economic activity. That is, by providing a sound business environment with proper rules and well-working basic institutions governments can unleash the potential of free markets.

The next chapter summarizes the findings of the dissertation, and considers potential future avenues for the research in international political economy. 


\section{CONCLUSION}

The proper role of government is an intriguing question for modern societies, i.e., trying to answer what governments do and why, what governments should not do, and finally, what governments should do? The general conclusion of public finance literature suggests that governments can, but do not necessarily, play a positive role in fostering economic progress. Past research has narrowed to a few general categories the reasons why governments sometimes fail to achieve desired outcomes. Governments may, among other things, disrupt the working of the invisible hand in the markets by altering the incentive structure individuals and firms face through taxation, regulation, etc., by basing policies on information that is inadequate or impossibly costly to come by, and finally, by failing to anticipate the potential of political systems to affect economic outcomes. The conclusion of the dissertation will summarize and discuss the findings of the previous chapters, and the importance of each of these findings will be reviewed. In addition, suggestions will be provided for future research in the area of international political economy given the existing literature and the contributions provided in the dissertation.

\subsection{Government growth and fiscal illusion}

The first essay in this dissertation examined the hypothesis that fiscal illusion is a significant factor in explaining the size of government. This is an important topic since the previous literature on government growth has suggested that the interaction between economic and politics may result in outcomes that are economically sub-optimal in terms of the size of governments. 
Fiscal illusion is the term generally used to describe a misperception of the amount of taxes an individual pays. There are several reasons why taxpayers may find it difficult to precisely estimate their tax burden. First, taxpayers often face many different types of taxes, and the more taxes there are, the more difficult it is for taxpayers to assess their total tax liability. This relationship is made even more difficult because some taxes may be more visible to taxpayers than others. Personal income taxes are generally more visible than excise taxes, for example. Second, because of tax shifting, actual tax incidence is often uncertain. Taxpayers would find it impossible in most cases to know how much tax is incorporated into the market prices they pay or income they earn. Third, individuals may fail to fully incorporate into their calculations the costs of compliance with the tax system. These costs can be substantial in terms of both money and effort.

Many researchers over the years have argued about the potential of the revenue structure to affect public spending, i.e., that the simpler the tax structure the easier it is for taxpayers to perceive the real cost of government, the more likely it is that the government has a smaller expenditure, and vice versa. Given the clear-cut theoretical premises of the fiscal illusion literature on revenue structure, the empirical results from testing the above hypothesis have been inconclusive. This is not overly surprising, though, due to the heavy reliance of previous literature on Herfindahl based measures of fiscal illusion. These have failed to take into account the qualitative differences of taxes in true tax perception of taxpayers.

The essay on fiscal illusion analyzed whether the complexity of a nation's revenue structure is a statistically significant variable in explaining government expenditure as a percentage of GDP in the framework of a median voter model. The sample consisted of 28 OECD countries, for which appropriate median income and public sector data are available 
for the years 1988 and 1993. The variables that were used to explain the size of government included the shares of females in labor force, of elderly in population, of trade in GDP, urbanization rate, per capita GDP, population, the ratio between median voter's income and the mean income, median voter's share in total taxes, and various fiscal illusion measures. In the regressions, the elderly's share in population, as well as the extent of international trade, turned out to be generally significant in explaining the size of government. The share of females in the labor force was significant in two, and per capita GDP in three, of the eight specifications. The coefficients for the urbanization rate, population, median voter, and median tax share were overwhelmingly of the correct sign, but insignificant. The constant, as well as the year dummy were consistently insignificant.

Of the various fiscal illusion measures, two of the three conventional Herfindahl measures had a wrong sign and all were insignificant. The same applied to the weighted Herfindahl index. Of the Herfindahl index variants only the Hannah-Kay measure was significant, but only at the $10 \%$ level. Put together, the Herfindahl based estimates did very little to strengthen the case for the fiscal illusion hypothesis. On the other hand, the remaining three fiscal illusion measures - two variations of the share of indirect taxes and the ratio of direct to indirect taxes - were all highly significant, but of the opposite sign than conventional wisdom suggests. The regression results for the indirect tax measures indicated that a $1 \%$ increase in the share of indirect taxes (two measures) decreased government expenditure as a share of GDP by $0.34 \%$ and $0.28 \%$, respectively. Alternatively, a $1 \%$ increase in the ratio of direct to indirect taxes increased the relative size of government by $0.23 \%$. These results stand in contradiction to the predictions of the fiscal illusion hypothesis in suggesting that heavier reliance on visible taxes, such as income taxes, is associated with larger government, or 
conversely, that the use of invisible taxes, such as excise taxes, is associated with smaller government.

The essay suggested that this result could stem from politicians' desire to minimize resistance for tax increases. Consequently, it was argued, an asymmetry in the power wielded by interest groups leads the largest and most heterogeneous groups to be the ones bearing the burden of new taxes. In this study, general taxpayers and direct taxes may fulfill that condition. This finding is consistent with theories that see politicians creating such tax structures that minimize voter resistance for new taxes.

Future research of the effects of tax structure on government growth has several potential directions. First, studies of fiscal illusion so far have utilized measures of illusion that have likely been less than perfect in terms of accuracy. Due to the lack of direct fiscal illusion measures an assumption has been made that particular quantitative measures of tax structure - mainly number of taxes- are adequate in measuring fiscal illusion. This approach alone is hardly satisfactory, though, since it omits the fact that some taxes are clearly more visible to taxpayers than others. In this respect, however, two promising avenues have recently presented themselves. Both laboratory experiments and survey data have lately been used to further refine our current understanding of the microfoundations of fiscal illusion. For instance, recent laboratory experiments have suggested that the type of taxes may be more important in creating uncertainty about the true cost of goods than the actual number of taxes.

When our understanding of the effects of tax structure on government size further increases, the next natural step would be - using various panel data based econometric techniques - to expand the sample used in this paper both in terms of countries and years. Since median income data is not readily available for a large sample of countries, alternative 
models to median voter in explaining government growth, such as probabilistic voting models, could also be tried.

When a better understanding of how the political process creates tax structures is acquired, a natural next step is to ask how societies can resist the creation of tax structures that are clearly not optimal from the welfare point of view. Here the focus would be on constitutional design, i.e., what kind of rules, or constraints, could be put in place to prevent politicians from using tax structure to their own advantage, potentially at the expense of larger society. Increased majority requirements in voting and earmarked spending are examples of political constraints that could in some cases be welfare-promoting.

As argued in section 2.1., the concept of fiscal illusion really has two sides. One is for politicians to create a complex tax structure that makes it difficult for taxpayers to identify their personal tax burden in the full. The other side is to create a simple spending structure that makes it easy for taxpayers to identify government programs that could potentially benefit them. Interestingly, I am not aware of any current papers that have looked into the latter. Thus, analysis of how the complexity/simplicity of spending structure affects government size would be a worthy addition to the current literature on government.

\subsection{The effectiveness of international development aid}

The second essay in the dissertation analyzed the effectiveness of international development aid. In fact, despite the steady flow of development aid to poor countries in the last fifty years, the results of this aid have been somewhat disappointing. Many countries in the developing world are still not unambiguously better off right now than they were 30 years ago. But even if development aid has not been as effective as the international community has wished, world 
leaders have been consistent in signaling their determination to improve the lot of the poorest countries. The $2001 \mathrm{UN}$ conference of 140 world leaders in Monterrey reiterated further support for the Millennium Development Goals - cutting in half the proportion of people living on less than one dollar a day, eliminating gender disparity in education, reducing child mortality by two-thirds, and developing a global partnership for development, among other things - that are to be achieved by 2015 .

How are these goals to be achieved? The World Bank, for instance, offers essentially a two-pronged solution: First, to double the current flow of aid to developing countries, and second, a new commitment to good governance on the part of the recipient countries. This study looks at whether an increase in the level of development aid - if structured as in the past - would likely result in increased future growth rates for developing countries. In addition, whether the quality of governance in the recipient country affects the results of aid was discussed.

Some, but not all, recent studies on development aid have found a positive relationship between aid and real per capita growth. Studies have also found that giving aid to politically liberal regimes has seemed to lead to lower infant mortality, suggesting an alternative way and rationale to aid distribution. Furthermore, a recent study argued that aid given to countries with good institutions and policies is far more likely to affect growth positively than aid given to countries of poor institutions and policies.

The essay in this dissertation on development aid covered 86 developing countries and the years 1975 - 1998. The dependent variable in the model was real GDP growth per capita. The independent variables were: initial level of GDP per capita, population growth, government consumption, human capital, investment, economic freedom of the world index, 
inflation, and foreign aid: in various specifications. The regressions results indicated a negative relationship between development aid and economic growth. In particular, it was found that a $1 \%$ increase in aid as a $\%$ of GDP decreased annual real GDP per capita growth by $3.65 \%$. Furthermore, aid given to countries with a better quality of governance was not found to improve the effectiveness of aid. It was suggested that these results may emanate from the negative effects of aid on work effort, and from the stipulated end uses of aid, that may lead to misallocation of scarce resources in the recipient country.

Overall, these findings do not provide support for the argument that development aid as in practice between 1975 and 1998 - has helped to boost growth rates in the developing world. The study also pointed out that the level of governance as measured by the economic freedom of the world index was a considerable factor in explaining growth in the sample. Based on these results it was argued that the current donor governments may be well advised to move more of their development focus from cash grants to programs that help to create sound institutional environments in recipient countries.

An interesting expansion of this essay could involve looking how the composition of aid affects economic outcomes. For instance, one could analyze in a large sample whether various end uses of aid, such as investment on education or health or infrastructure, have yielded different returns in terms of economic growth. A closely related topic would be to compare the aid effectiveness of tied aid versus untied aid. Even though tying aid is the prevalent practice of international donors, possibly because of reasons of their domestic politics or worries about the potential misuse by recipient governments, there is very little research on whether this is the best practice in distributing aid. 
Another unexplored topic in aid research involves the comparison of donor effectiveness. Possibly because aid giving in general is considered as an unselfish and, as such, a commendable act, both the recipient countries, and international aid organizations and their research staff have traditionally to some degree abstained from comparing the aid effectiveness of donors. However, transparency in discussing aid results by donor could make aid more effective. Politicians of those donor countries whose aid proves consistently ineffective compared to a peer group would likely feel pressure from their own electorate to improve. This would be a positive development. Paying increasing attention to donors could then be an additional new way to extract improved results from aid. In the end, there is no reason why accountability should not apply equally to either side of the aid process.

Yet another interesting new avenue would be to explore the effectiveness of aid that does not rely upon the current type lump-sum contributions but rather upon opening the donor's markets for recipients' products. On theoretical grounds this approach has two-fold benefits. First, this would do away with the negative effects aid may impose upon work effort in recipient countries. Second, this solution relies upon markets, yielding benefits of trading to both donors and recipients, which may make it politically more palatable. Furthermore, the market based solution has potential to reduce the administrative cost of aid distribution significantly.

\subsection{Entrepreneurship in post-socialist economies}

Entrepreneurial activity has been shown to be an important factor in fostering economic growth and job creation. Entrepreneurs are agents of change, they transform innovative ideas into commercial opportunities, and act as a countervailing power to larger firms' monopolistic 
aspirations. Entrepreneurial risk taking leads to new and improved products, makes societies more apt to change, and ultimately, helps societies to improve their allocation of scarce resources. An important question to any economy is then how to encourage entrepreneurial activity.

What are the determinants of entrepreneurial activity? Previous literature hints towards three main points. First, proper institutional arrangements need to be in place. Welldefined property rights serve as an example. Second, government policies, such as taxation and monetary arrangements, also play an important role in fostering entrepreneurship. Third, cultural factors and initial conditions, such as general attitudes towards risk taking and business enterprises, and initial levels of income also help to explain why the level entrepreneurial activity may be high or low.

The essay on entrepreneurship looked at how governments can reduce the marginal cost of entrepreneurial risk bearing in post-socialist economies, and consequently, suggested a policy prescription for transition economies on how to foster entrepreneurial activity. The sample consisted of ten Baltic and Central-European economies that generally started their transition process in the early 1990s. The period considered covered years 1995-2000. The case of transition economies is of particular interest since each post-socialist country essentially started from a zero-point the creation of market system compatible environments and during the process of transition have made many unique, country-specific choices. Not only did every country - or rather, government - have to choose how quickly to proceed with transition, but also, how to sequence the reforms. The considerable variation in these choices provides a fertile ground to test which choices turned out to be the best in fostering entrepreneurship. 
In the empirical model, entrepreneurial activity - as measured by the number of new firms and patent and trademark applications - is explained by variables that fall into the three determinant categories listed before. The exogenous variables include, among others, quality of infrastructure, initial income, credit availability, corruption, and economic freedom in general.

The factors most significant in explaining new enterprise creation were found to be credit availability, non-performing loans, government corruption, and inflation rates. In particular, the index of government corruption was highly significant, and negative, in all specifications. It is clear that a sound political process is essential to fostering new enterprise creation. However, government corruption was more significant in hampering the creation rate of smaller firms than of larger ones. Larger firms are more likely to be able to use the political process to their advantage, so it is reasonable to expect that small firm creation is harmed to a greater extent by the presence of government corruption.

In explaining entrepreneurial activity as measured by patent and trademark applications, an entirely different set of important explanatory variables emerges. GDP per capita is significant and positive in explaining the level of patent and trademark activity. Because this type of high-tech entrepreneurship requires a substantially greater degree of resources to undertake, this result is reasonable. However, even with this variable omitted, the same two additional variables are significant in the regression. The first of these is the index of economic freedom. This measure of sound government policy coupled with low taxes and regulations is highly significant and positively related to the level of patent and trademark activity. This result is consistent with similar empirical studies of entrepreneurship. The final significant variable is net foreign direct investment, and it is also positive in the regression. It 
appears that countries can, to a certain extent, import this type of high-tech innovation from other countries through foreign direct investment.

Despite the fact that two different subsets of variables are significant when comparing the results for two alternative dependent variables, one of the most interesting findings is that there are two variables, government provided infrastructure and import tariffs, that are insignificant in both cases. Based on this one can conclude that protectionist tariffs cannot, and do not, accomplish higher rates of domestic entrepreneurial activity. In addition, government provided infrastructure is not nearly as important as the other policies of government reflected in things such as less government corruption and higher levels of economic freedom (low taxes, low regulations, and secure private property rights).

Put together, the results clearly point to several key factors associated with high rates of entrepreneurial activity in post-socialist transition economies. These include credit availability, contract enforcement, low government corruption, sound monetary policy, high foreign direct investment, and policies (such as low regulations and taxes) that are consistent with giving citizens a high degree of economic freedom.

What the results also suggest is that having policies that simply help the rate of new firm creation do not automatically also promote the high rates of technological innovation necessary for economic growth. Of the two measures, patent and trademark activity is more highly correlated with economic growth than is new firm creation. To be successful, postsocialist countries not only need to institute policies consistent with fostering the creation of new businesses, but also must have in place policies conducive with fostering new high-tech innovation. One of the most important of these factors is the presence of economic freedom low taxes, low regulations, and secure private property rights. As discussed in the first chapter 
of the dissertation, this finding provides further support to the idea of governments as enablers of economic activity. That is, for governments to provide a sound business environment with proper rules and well-working basic institutions is often enough to unleash the potential of free markets.

Large-scale research on entrepreneurship in post-socialist economies is still hampered by incomplete data availability. Figures from the early 1990s are often either missing or of bad statistical quality. Moreover, since data collection and classification procedures in the early stages of transition varied widely from country to country, the data is often not suitable for international comparisons. Thanks to the efforts of many international organizations and western governments, the statistics on post-socialist economies have steadily improved, though. The most promising new data series contain survey type information that several international organizations have started to collect on changes in business environment. These surveys include the "Executive Opinion Survey" by the World Economic Forum, and "Business Environment and Enterprise Performance Survey" by the European Bank for Reconstruction and Development and the World Bank, and typically measure the perceptions of local businessmen towards variables such as the rule of law, level of competition, quality of education and administrative red tape. ${ }^{23}$

In the near future the above time series type of data on business environments should enable researchers to run more advanced panel data regressions on a large set of countries. This is a great improvement over the current state of affairs where time series data is available for a rather limited set of countries, mostly countries that have forged a close relationship with the European Union. Besides panel data set-ups, one currently available option for researchers

\footnotetext{
${ }^{23}$ For details, see: Porter, Michael E., Jeffrey D. Sachs, Peter K. Cornelius, John W. McArthur \& Klaus Scwab (2002) and EBRD (1999).
} 
is to pursue cross-sectional studies on all the $(30+)$ post-socialist countries. This approach can also be defended, although it poses some difficult methodological problems. Above all, transition economies by their nature still show large changes in their macroeconomic stability from year to year. Accordingly, one year cross-section is quite sensitive to the choice of year. When using cross-section one would therefore want to resort to averaging over years to smooth the annual variation, which brings one back to the lack of good quality data from the early transition years. Overall, the post-socialist economies hold great promise in providing a fertile testing ground for some of the latest advances in institutional growth theories, which are considerably more difficult to test in the sample of already high scoring western market economies than in the sample of fast moving transition countries that show considerable variation among their policies and institutional environments.

\subsection{Government and the economy}

The dissertation started by asking what governments actually do and why, what governments should avoid doing, and finally, what governments should undertake to foster economic progress. Based on the findings of the three essays in the dissertation and on previous public finance literature, the following proposal can be made. From the point of view of economic progress, one may suggest that people in general would be well served by the kind of societies in which individuals have strong incentives to work hard and to constantly improve the status quo. Achieving this calls for a high-quality institutional environment. In this scheme government is in the center of creating the stable institutional framework that well-working markets, and consequently, flourishing individual initiative, require. However, political systems - because of their inherent systemic shortcomings that are vividly described in public 
economics literature - sometimes fail to provide desired economic outcomes. Therefore, it may be in the interest of societies to limit the potential scope of action of governments by placing such behavioral constraints on it - be it in the sphere of taxation, regulation or spending - that reduce its tendency to branch out to new areas of economic activity. This is an idea with which I believe the venerable Adam Smith would concur. 


\section{APPENDIX A: Government Growth and Fiscal Illusion}

\section{A.1. List of countries.}

Australia
Austria
Belgium
Canada
Czech Republic*
Denmark
Finland
France
Germany*
Greece
Hungary*
Ireland
Italy
Japan
Korean Republic
Luxembourg
Mexico
Netherlands
New Zealand
Norway
Poland*
Portugal
Spain
Sweden
Switzerland
Turkey
United Kingdom
United States.

* Missing data, not included for 1988. 


\section{A.2. Descriptive statistics}

All results based on nonmissing observations - 28 countries.

\begin{tabular}{|c|c|c|c|c|c|}
\hline Variable & Mean & Std.Dev. & Minimum & Maximum & Cases \\
\hline $\begin{array}{l}\text { Females in labor force } \\
\text { (\% of total labor force) }\end{array}$ & 40.51 & 4.69 & 29.38 & 47.76 & 51 \\
\hline $\begin{array}{l}\text { Share of elderly in population } \\
\text { (\% of total population) }\end{array}$ & 12.82 & 3.25 & 3.86 & 17.80 & 51 \\
\hline $\begin{array}{l}\text { Trade } \\
(\% \text { of GDP })\end{array}$ & 65.38 & 40.94 & 16.31 & 223.5 & 51 \\
\hline $\begin{array}{l}\text { Urbanization rate } \\
\text { (\% of total population) }\end{array}$ & 74.12 & 11.82 & 42.90 & 96.80 & 51 \\
\hline $\begin{array}{l}\text { GDP per capita } \\
\text { (in dollars) }\end{array}$ & 20800 & 10915 & 2557 & 43831 & 51 \\
\hline $\begin{array}{l}\text { Population } \\
\text { (in millions) }\end{array}$ & 37.12 & 53.41 & 0.37 & 258.2 & 51 \\
\hline $\begin{array}{l}\text { Ratio of median to } \\
\text { mean income }\end{array}$ & 0.84 & 0.07 & 0.57 & 0.93 & 51 \\
\hline $\begin{array}{l}\text { Median tax share of } \\
\text { an individual }\end{array}$ & $0.88 \mathrm{E}-05$ & $0.19 \mathrm{E}-04$ & $0.72 \mathrm{E}-09$ & $0.98 \mathrm{E}-04$ & 51 \\
\hline $\begin{array}{l}\text { Herfindahl index } \\
\text { (six tax categories) }\end{array}$ & 0.33 & 0.05 & 0.26 & 0.47 & 51 \\
\hline $\begin{array}{l}\text { Herfindahl index } \\
\text { (nine tax categories) }\end{array}$ & 0.27 & 0.06 & 0.21 & 0.51 & 51 \\
\hline $\begin{array}{l}\text { Herfindahl index } \\
\text { (eleven tax categories) }\end{array}$ & 0.20 & 0.06 & 0.11 & 0.45 & 51 \\
\hline $\begin{array}{l}\text { Weighted Herfindahl index } \\
\text { (nine tax categories) }\end{array}$ & 0.21 & 0.06 & 0.15 & 0.45 & 51 \\
\hline $\begin{array}{l}\text { Hannah-Kay index } \\
\text { (nine tax categories) }\end{array}$ & 4.80 & 1.08 & 2.70 & 9.95 & 51 \\
\hline $\begin{array}{l}\text { Share of indirect taxes } 1 \\
\text { (specification } 1)\end{array}$ & 44.69 & 11.93 & 24.50 & 73.10 & 51 \\
\hline $\begin{array}{l}\text { Share of indirect taxes } 2 \\
\text { (specification } 2 \text { ) }\end{array}$ & 29.91 & 8.85 & 14.30 & 50.80 & 51 \\
\hline $\begin{array}{l}\text { Ratio of direct to } \\
\text { indirect taxes }\end{array}$ & 1.41 & 0.67 & 0.37 & 3.08 & 51 \\
\hline
\end{tabular}




\section{A.3. Variable explanations and data sources}

Variable

Explanation

Data source

Government expenditure

Share of females in labor force

Share of people 65 years of age and older in total population

Share of trade

Urbanization rate

Per capita GDP

Population

The ratio between median voter's income and the mean income

Median voter's share in total taxes

Herfindahl index of tax complexity
Government expenditure as a percentage of GDP.

GFSY, RS

The higher the participation rate, the more demand there is for

WDI government provided services - such as day care and schooling - that have previously been taken care of by females.

The higher the share of retired people in society the higher the demand for income redistribution

Movements towards freer trade usually result in employment losses in sectors of non-comparative advantage. Consequently, workers in those sectors will organize and through special interest groups demand income redistribution to share part of the national gain from freer trading.

Urbanization leads to social conflicts that call for increased spending on law and order, among other things.

Rising incomes increase demand for goods and services, such as basic sanitation, health care and education, in which' provision governments have frequently had a central role.

Due to non-excludability and economies of scale, the average cost of providing public goods decreases with increasing population, resulting in increased demand for public goods.

The farther away the decisive median voter is in terms of income from society's average income, the higher the demand for income transfers to close the gap.

Measures the cost of the public goods. The lower the number the higher should the demand be for public sector goods and services. Median voter's share in total taxes $=$ [Average Tax Rate * Median Income]/Total Tax Revenue, where ATR = (Total Tax Revenue/GDP).

$\sum_{i=n}^{n} R_{i}^{2}$, where n refers to the number of tax categories and $\mathrm{R}$ to the share of each tax category in total tax revenues. A measure of fragmentation of a tax system. The higher the index, the more visible the taxes. The index was calculated separately with six, nine and eleven tax categories. GFSY, RS

WDI

WDI

WDI

WDI

WDI

Milanovic

WDI, Milanovic 
Weighted Herfindahl index of tax complexity

Hannah-Kay index of tax complexity

The share of indirect taxes in total tax revenues

The ratio of direct to indirect taxes $\sum_{i=1}^{n}\left(\phi_{i} R_{i}\right)^{2}$, where $\mathrm{n}$ refers to the number of tax categories,

GFSY, RS

$\phi$ to the weight assigned to each category and $\mathrm{R}$ to the share of each tax category in total tax revenues. A measure of fragmentation of a tax system. The higher the index the more visible the taxes. Using the findings of Tyran \& Sausgruber (2000), $\phi$ was assigned a value of 0.73 for indirect and 1 for direct taxes. The index was calculated with nine tax categories.

$\left(\sum_{i=1}^{n} R_{i}^{\alpha}\right)^{(1 / 1-\alpha)}$, where $\mathrm{n}$ refers to the number of tax

GFSY, RS

categories, $\alpha$ to the weight assigned to each observation and $\mathrm{R}$ to the share of each tax category in total tax revenues. A measure of fragmentation of a tax system. The higher the index the more visible the taxes. Using the findings of Heyndels \& Smolders (1995), $\alpha$ was assigned a value of 0.9 . The index was calculated with nine tax categories.

Indirect taxes are harder to identify than direct taxes, such as personal income taxes, and may therefore lead taxpayers to underestimate their personal tax burden. Two specifications were used.

When the relative share of direct taxes in total taxes rises, the visibility of taxation should improve, lessening fiscal illusion.

GFSY, RS

The keys to data sources:

WDI: The World Bank (2001): "World Development Indicators 2001," Washington, D.C..

Milanovic: Milanovic, Branko (1999): "True world income distribution, 1988 and 1993. First calculation based on household surveys alone," The World Bank, Washington, D.C.

GFSY: IMF (1997):"Government Finance Statistics Yearbook 1997," Washington, D.C..

RS: OECD (2000): "Revenue Statistics 2000," Paris. 


\section{A.4. Composition of fiscal illusion variables}

HER 6 (OECD):

HER 9 (GFSY):

HER 11 (GFSY):

WEIGHTED HER 9:

HANNAH-KAY 9:

INDIRECT 1 (GFSY):

INDIRECT 2 (GFSY): DIRECT/ INDIRECT
1000-6000.

IV (1-7), V, VI.

IV $(1.1,1.2,2.1,2.2,3-7), \mathrm{V}, \mathrm{VI}$.

See HER 9; IV $(2,3,5,6)$ multiplied by 0.73 .

See HER 9.

IV $(1.2,2.2,3,5,6)$.

IV $(1.2,2.2,3,5.2,6)$.

(1 - INDIRECT 1) / INDIRECT 1.

where the keys are:

OECD Revenue Statistics 2000:

1000 Taxes on income, profits and capital gains

2000 Social security contributions

3000 Taxes on payroll and workforce

4000 Taxes on property

5000 Taxes on goods and services

6000 Other taxes

IMF Government Finance Statistics Yearbook (GFSY) 1997:

IV.1. Taxes on income profits and capital gains

IV.1.1. Individual

IV.1.2. Corporate

IV.2. Social security contributions

IV.2.1. Employees

IV.2.2. Employers

IV.3. Taxes on payroll or work force

IV.4. Taxes on property

IV.5. Domestic taxes on goods and services

IV.5.1. General sales, turnover or value-added taxes

IV.5.2. Excises

IV.6. Taxes on international trade and transactions

IV.7. Other taxes

V. Nontax revenue

VI. Capital revenue 


\section{APPENDIX B: The Effectiveness of International Development Aid}

\section{B.1. List of countries}

\begin{tabular}{|c|c|c|}
\hline Albania & Fiji & Nigeria \\
\hline Algeria & Gabon & Oman \\
\hline Argentina & Ghana & Pakistan \\
\hline Bahamas, The* & Guatemala & Panama \\
\hline Bahrain* & Guinea-Bissau & Papua New Guinea \\
\hline Bangladesh & Guyana & Paraguay \\
\hline Barbados & Haiti & Peru \\
\hline Belize & Honduras & Philippines \\
\hline Benin & Hong Kong* & Rwanda \\
\hline Bolivia & India & Senegal \\
\hline Botswana & Indonesia & Sierra Leone \\
\hline Brazil & Iran, Islamic Rep. & Singapore* \\
\hline Burundi & Israel* & Slovenia* \\
\hline Cameroon & Jamaica & South Africa* \\
\hline Central African Republic & Jordan & Korea, Rep. \\
\hline Chad & Kenya & Sri Lanka \\
\hline Chile & Kuwait & Tanzania \\
\hline China & Madagascar & Thailand \\
\hline Colombia & Malawi & Togo \\
\hline Congo, Dem. Rep.* & Malaysia & Trinidad and Tobago \\
\hline Congo, Rep. & Mali & Tunisia \\
\hline Costa Rica & Malta & Turkey \\
\hline Cote d'Ivoire & Mauritius & Uganda \\
\hline Croatia* & Mexico & United Arab Emirates* \\
\hline Cyprus* & Morocco & Uruguay \\
\hline Dominican Republic & Namibia* & Venezuela, RB \\
\hline Ecuador & Nepal & Zambia \\
\hline Egypt, Arab Rep. & Nicaragua & Zimbabwe \\
\hline El Salvador & Niger & \\
\hline
\end{tabular}

*EDA not available 


\section{B.2. Descriptive statistics}

All results based on nonmissing observations - 86 countries.

\begin{tabular}{|c|c|c|c|c|c|}
\hline Variable & Mean & Std.Dev. & Minimum & Maximum & Cases \\
\hline $\begin{array}{l}\text { Real GDP per capita growth } \\
\text { (average annual } \% \text { change) }\end{array}$ & 1.15 & 3.50 & -11.51 & 13.55 & 413 \\
\hline $\begin{array}{l}\text { Initial level of GDP per capita } \\
\text { (in log dollars) }\end{array}$ & 7.15 & 1.28 & 0.86 & 10.54 & 415 \\
\hline $\begin{array}{l}\text { Population growth } \\
\text { (average annual \% change) }\end{array}$ & 2.32 & 1.31 & -6.19 & 16.13 & 435 \\
\hline $\begin{array}{l}\text { Government consumption } \\
(\% \text { of GDP) }\end{array}$ & 14.41 & 6.19 & 1.41 & 48.06 & 409 \\
\hline $\begin{array}{l}\text { Secondary education } \\
\text { (\% of age group) }\end{array}$ & 43.41 & 25.30 & 0.00 & 100.0 & 403 \\
\hline $\begin{array}{l}\text { Life expectancy } \\
\text { (in log years) }\end{array}$ & 4.09 & 0.19 & 3.53 & 4.37 & 434 \\
\hline $\begin{array}{l}\text { Investment } \\
(\% \text { of GDP) }\end{array}$ & 21.94 & 7.71 & 3.58 & 52.43 & 416 \\
\hline $\begin{array}{l}\text { Economic Freedom of the } \\
\text { World index (scale: } 0-10)\end{array}$ & 5.35 & 1.10 & 1.77 & 9.06 & 382 \\
\hline $\begin{array}{l}\text { Inflation } \\
\text { (GDP deflator, \%) }\end{array}$ & 70.31 & 434.6 & -3.41 & 6962 & 419 \\
\hline $\begin{array}{l}\text { Aid }(\text { ODA }) \\
(\% \text { of GDP) }\end{array}$ & 5.44 & 7.82 & 0.00 & 55.36 & 435 \\
\hline Aid (ODA) x EFW & 26.75 & 34.04 & 0.00 & 171.5 & 382 \\
\hline $\operatorname{Aid}^{2}(\mathrm{ODA})$ & 90.69 & 287.1 & 0.00 & 3064 & 435 \\
\hline Aid (EDA) & 4.37 & 6.02 & -0.08 & 39.07 & 287 \\
\hline Aid (EDA) x EFW & 20.21 & 25.42 & -0.47 & 123.2 & 252 \\
\hline $\mathrm{Aid}^{2}(\mathrm{EDA})$ & 55.19 & 162.3 & 0.00 & 1526 & 287 \\
\hline Population (in millions) & 40.03 & 144.4 & 0.14 & 1225 & 435 \\
\hline $\begin{array}{l}\text { Infant mortality } \\
\text { (per thousand live births) }\end{array}$ & 33.49 & 11.08 & 0.00 & 56.88 & 434 \\
\hline $\begin{array}{l}\text { Illiteracy rate } \\
\text { ( } \% \text { of adult population) }\end{array}$ & 33.36 & 23.51 & 0.40 & 93.02 & 420 \\
\hline $\begin{array}{l}\text { GDP per capita } \\
\text { (in dollars) }\end{array}$ & 2949 & 4542 & 119.0 & 34517 & 414 \\
\hline
\end{tabular}




\section{B.3. Variable explanations and data sources}

Variable

Explanation

Data source

Real GDP growth per
capita
Initial level of GDP per
capita

Population growth

Government consumption

Secondary education

Life expectancy

Investment

Economic freedom of the world index

Inflation

Official development assistance (ODA)

Efficient development assistance (EDA)
Inflation adjusted annual output growth.

WDI

Measures the conditional rate of convergence of the economy to its long-run position. Based on the neoclassical growth model the coefficient of the initial GDP should be negative, i.e., the higher the initial income level the slower the growth.

Population growth decreases the share of capital per worker and is therefore expected to slow economic growth. This effect may be reinforced by the fact that additional productive resources are redirected for child care.

Approximates the public sector spending that does not contribute to an increase in nation's productivity. An increasing government consumption is associated with higher tax rates and lower work incentives for the population.

Measures the level of human capital that raises the skill level of population, and therefore, total productivity.

Reflects the general health status of population, a larger number signaling a higher likelihood for economic growth.

A higher investment ratio increases the amount of capital per worker, and therefore, total productivity and economic growth.

Approximates the level of freedom in a society as measured by the levels of personal choice, voluntary exchange, competition and protection of person and property. A higher index number associated with better governance, and potentially, higher economic growth.

Measures change in annual price level. In an environment of high/unpredictable inflation people are more likely to refrain from potentially productive projects.

Foreign aid is expected to raise the level of savings in society, and through investment increase the level of economic growth. On the other hand, foreign aid may also crowd out domestic investment, decrease work effort, and if tied to unproductive projects, may lead to slower growth.

Foreign aid is expected to raise the level of savings in society, and through investment increase the level of economic growth. On the other hand, foreign aid may also crowd out domestic investment, decrease work effort, and if tied to unproductive projects, may actually lead to slower growth.
WDI

WDI

WDI

WDI

WDI

WDI

Gwartney et al

WDI

WDI, IDS

Chang et al 
Instruments for aid:

Level of income per capita Poorer countries generally get more foreign aid. WDI

Population $\quad$ Smaller countries tend to receive more per capita aid than WDI large ones.

Infant mortality

Illiteracy rate
A human development indicator that is considered as an

WDI important factor when donors make decisions on granting aid.

A human development indicator that is considered as an important factor when donors make decisions on granting aid.

The keys to data sources:

WDI: The World Bank (2001): "World Development

Indicators 2001," Washington, D.C.

Chang et al: Chang, Charles C., Eduardo Fernandez-Arias \& Luis Serven (1999): "Measuring aid flows: A new approach," The World Bank, Development Economics Research Group, Washington, D.C.

Gwartney et al: Gwartney, James \& Robert Lawson with Walter Park, Smita Wagh, Chris Edwards, and Veronique de Rugy (2002): "Economic Freedom of the World: 2002 Annual Report," The Fraser Institute, Vancouver, B.C. Data retrieved from www.freetheworld.com

IDS: OECD (2001): "International Development Statistics 2001," Paris. 
APPENDIX C: Entrepreneurship in Post-Socialist Economies

\section{C.1. List of countries}

Bulgaria

Czech Republic

Estonia

Hungary

Latvia

Lithuania

Poland

Romania

Slovak Republic

Slovenia 


\section{C.2. Descriptive statistics}

All results based on nonmissing observations - 10 countries.

\begin{tabular}{|c|c|c|c|c|c|}
\hline Variable & Mean & Std.Dev. & Minimum & Maximum & Cases \\
\hline $\begin{array}{l}\text { New enterprises } \\
\text { (per } 1000 \text { people) }\end{array}$ & 4.67 & 2.44 & 1.65 & 12.60 & 60 \\
\hline $\begin{array}{l}\text { New small firms } \\
\text { (per } 1000 \text { people) }\end{array}$ & 4.63 & 2.43 & 1.60 & 12.47 & 60 \\
\hline $\begin{array}{l}\text { New large firms } \\
\text { (per } 1000 \text { people) }\end{array}$ & 0.038 & 0.026 & 0.022 & 0.126 & 60 \\
\hline $\begin{array}{l}\text { Patent and trademark } \\
\text { applications (per } 1000 \text { people) }\end{array}$ & 0.45 & 0.16 & 0.16 & 0.86 & 60 \\
\hline $\begin{array}{l}\text { GDP per capita } \\
\text { (constant } 1995 \text { dollars) }\end{array}$ & 3915 & 2566 & 1317 & 11659 & 60 \\
\hline $\begin{array}{l}\text { EBRD index of infrastructure } \\
\text { reform (range: } 1 \text { to } 4.3 \text { ) }\end{array}$ & 2.43 & 0.61 & 1.00 & 3.70 & 60 \\
\hline $\begin{array}{l}\text { Credit availability } \\
\text { (\% of loans of GDP) }\end{array}$ & 24.58 & 14.44 & 7.18 & 65.72 & 59 \\
\hline $\begin{array}{l}\text { Non-performing loans } \\
\text { (\% of total) }\end{array}$ & 17.71 & 13.72 & 1.60 & 58.50 & 58 \\
\hline $\begin{array}{l}\text { Government corruption } \\
\text { (range: } 1 \text { to } 5 \text { ) }\end{array}$ & 3.26 & 0.64 & 2.00 & 5.00 & 57 \\
\hline $\begin{array}{l}\text { Index of economic freedom } \\
\text { (range: } 1 \text { to } 5 \text { ) }\end{array}$ & 2.95 & 0.42 & 2.20 & 3.65 & 57 \\
\hline $\begin{array}{l}\text { Net foreign direct investment } \\
\text { ( } \% \text { of GDP) }\end{array}$ & 4.33 & 2.85 & 0.69 & 11.56 & 60 \\
\hline $\begin{array}{l}\text { Import tariffs } \\
\text { (\% of GDP) }\end{array}$ & 4.15 & 2.75 & 0.00 & 12.48 & 58 \\
\hline $\begin{array}{l}\text { Inflation } \\
\text { (annual \% change) }\end{array}$ & 34.75 & 122.8 & 0.86 & 949.1 & 60 \\
\hline
\end{tabular}




\section{C.3. Variable explanations and data sources}

Variable Explanation Data source

New enterprises

New small firms

New large firms

Patent and trademark applications

Real GDP per capita

Infrastructure reform index

Credit availability

Non-performing loans

Government corruption
This measure covers registrations of new enterprises on the

EUROSTAT business registers of each country during the corresponding time periods, excluding agricultural, public administration and private non-profit enterprises as well as enterprises that were reregistered because of privatization or co-operative split.

Number of new enterprises with 49 or less employees.

Number of new enterprises with 50 or more employees.

Includes the number of patent and trademark applications filed by domestic residents during a calendar year.

Inflation adjusted measure of annual output of goods and services.

This index measures the quality of government provided infrastructure services, taking into account accomplished reforms that foster the potential future development of infrastructure. The index is comprised of five sectors (telecommunications, electric power, railways, roads, and water and waste) and ranges from 1 to 4.3 (higher is better).

Credit availability approximates the level of domestic credit provision to private sector. The measure includes loans, types c of securities, trade credits and other accounts receivable that require a repayment. This variable also measures the level of trust people have in banks (keeping deposits safe) and possibly property rights in general.

Non-performing loans is measured as a ratio to total loans. It is used here to approximate the level consumers/firms in the economy that complete a transaction but are currently unable to pay for the particular good or service. This variable also measures the extent of property rights and rule of law in as far as a higher number implies that a portion of people default with the hope of the creditor being unable to challenge the unpayment.

The government corruption variable relies mostly on Transparency International's corruption perceptions index which measures the degree to which corruption is perceived to exist in the public sector. Corruption is defined as the abuse of public office for private gain. This measure ranges from 1 to 5 , higher meaning more corrupt.
EUROSTAT

EUROSTAT

WIPO

WDI

EBRD

WDI

EBRD

IEF 
Index of economic freedom

Net foreign direct investment

Import tariffs

Inflation
The index is composed of 50 variables that have been divided

IEF into ten headings that together measure the economic freedom of a country, i.e., freedom from government interference in daily economic life. Past studies have identified a clear correlation between economic freedom and growth. The index values range between 1 and 5 , higher meaning less free. A reversed scale was used in this study.

Foreign direct investment is net inflows of investment to WDI acquire a lasting management interest (10 percent or more of voting stock) in an enterprise operating in an economy other than that of the investor. It is the sum of equity capital, reinvestment of earnings, other long-term capital, and shortterm capital as shown in the balance of payments.

Import duties comprise all levies collected on goods at the point of entry into the country, and generally have a negative effect on the domestic level of competition.

Measures change in annual price level. In an environment of high/unpredictable inflation people are more likely to refrain from potentially productive projects.

The keys to data sources:

WDI: The World Bank (2001): "World Development

Indicators 2001," Washington, D.C.

EBRD: EBRD (2002): "Transition Report 2002," London.

EUROSTAT: Eurostat (2002): "New enterprises and development of enterprises in Central-European countries," Luxembourg.

IEF: O'Driscoll, Jr., Gerald P., Edwin J. Feulner \& Mary Anastasia O'Grady, with Ana I. Eiras and Brett D. Schaefer: (2003): "2003 Index of Economic Freedom," The Heritage Foundation and The Wall Street Journal, Washington D.C. and New York.

WIPO: World Intellectual Property Organization. Data retrieved from www.wipo.org. 


\section{REFERENCES}

Acs, Zoltan J. (2003): "What is the value of entrepreneurial start-ups to an economy?," in Varga, Attila \& László Szerb (Eds.): "Innovation, entrepreneurship, regions and economic development: international experiences and Hungarian challenges," University of Pécs, Pécs, Hungary, pp. 81-106.

Alesina, Alberto \& Beatrice Weder (2002): "Do corrupt governments receive less foreign aid?," American Economic Review, vol. 92, no. 4, pp. 1126-1137.

Ali, Abdiweli A. \& W. Mark Crain (2002): "Institutional distortions, economic freedom, and growth," Cato Journal, vol. 21, no. 3, pp. 415-426.

Arrow, Kenneth (1951): "Social choice and individual values," 2d. ed., Wiley, New York.

Baker, Samuel H. (1983): "The determinants of median voter tax liability: an empirical test of the fiscal illusion," Public Finance Quarterly, 11 (January), pp. 95-108.

Barro, Robert J. (1997): "Determinants of economic growth: a cross-country empirical study," The MIT Press, Cambridge, Massachusetts.

Bartley, Robert L. (2001): "Time for honesty in taxation," The Wall Street Journal, November 5,pg. A21.

Baumol, William (1968): "Entrepreneurship in economic theory," American Economic Review, Papers and proceedings of the eightieth annual meeting of the American economic association, vol. 58, issue 2, pp. 64-71.

Baumol, William J. (1990): "Entrepreneurship: productive, unproductive, and destructive," Journal of Political Economy, vol. 98, issue 5, part 1, pp. 893-921.

Becker, Gary S. (1983): “A theory of competition among pressure groups for political influence," Quarterly Journal of Economics, vol. XCVIII, no. 3, pp. 371- 400.

Berkowitz, Daniel \& David N. DeJong (2001): "Entrepreneurship and post-socialist growth," William Davidson Working Paper Number 406.

Black, Duncan (1948): "On the rationale of group decision making," Journal of Political Economy, 56, 1, pp. 23-34.

Boone, Peter (1996): "Politics and the effectiveness of foreign aid," European Economic Review, 40, pp. 289-329.

Bovard, James (1986): "The continuing failure of foreign aid," Policy Analysis, no. 65. 
Bowen, Howard (1943): "The Interpretation of voting in the allocation of economic resources," Quarterly Journal of Economics, vol. 58, pp. 27-48.

Breeden, Charles H. \& William J. Hunter (1985): "Tax revenue and tax structure," Public Finance Quarterly, 13 (April), pp. 216-224.

Brennan, Geoffrey \& James M. Buchanan (1980): "The power to tax: analytical foundations of a fiscal constitution," Cambridge University Press, Cambridge.

Buchanan, James \& Gordon Tullock (1962): "The calculus of consent: logical foundations of a constitutional democracy," University of Michigan Press, Ann Arbor.

Buchanan, James (1990): "The domain of constitutional politics," Constitutional Political Economy, vol. 1, no. 1, pp. 1-18.

Buchanan, James M. (1967): "Public finance in democratic process: fiscal institutions and individual choice," University of North Carolina Press, Chapel Hill.

Burnside, Graig \& David Dollar (2000): “Aid, policies and growth," American Economic Review, vol. 90, no. 4, pp. 847-868.

Carlsson, Fredrik \& Susanna Lundström (2002): "Economic freedom and growth: decomposing the effects," Public Choice, vol. 112, pp. 335-344.

Chang, Charles C., Eduardo Fernandez-Arias \& Luis Serven (1999): "Measuring aid flows: a new approach," The World Bank, Development Economics Research Group, Washington, D.C.

Clotfelter, Charles T. (1976): "Public spending for higher education: an empirical test of two hypotheses," Public Finance, vol. 31, no. 2, pp. 177-195.

Cullis, J. \& A. Lewis (1985): "Some hypotheses and evidence on tax knowledge and preferences," Journal of Economic Psychology, vol. 6, pp. 271-287.

Cullis, J. \& P. R. Jones (1987): "Fiscal illusion and excessive budgets: some indirect evidence," Public Finance Quarterly, 15, pp. 219-228.

Cullis, John \& Philip Jones (1998): "Public finance and public choice," Second edition, Oxford University Press, Oxford.

Dalgaard, C.-J., H. Hansen \& F. Tarp (2000): "Aid effectiveness disputed," Journal of International Development, 12, pp. 375-398.

Devarajan, Shantayanan, David Dollar \& Torgny Holmgren (Eds.) (2001): "Aid and reform in Africa: lessons from ten case studies," The World Bank, Washington, D.C. 
Dollery, B. \& A.C. Worthington (1996): "The empirical analysis of fiscal illusion," Journal of Economic Surveys, 10(3), pp. 261-297.

Downs, Anthony (1957): “An economic theory of democracy," Harper \& Row, New York.

Earle \& Sakova (1999): "Entrepreneurship from scratch: lessons on the entry decision into self-employment from transition economies," IZA Discussion Paper No. 79, Bonn, Germany.

Easterly, William \& Ross Levine (2001): "It's not factor accumulation: stylized facts and growth models," The World Bank Economic Review, vol. 15, no. 2, pp. 177-219.

Easterly, William (2001): “The elusive quest for growth: economists' adventures and misadventures in the tropics," The MIT Press, Cambridge, Massachusetts.

EBRD (1999): "Transition report 1999: ten years of transition," European Bank for Reconstruction and Development, London.

EBRD (2002): "Transition report 2002: agriculture and rural transition," European Bank for Reconstruction and Development, London.

Eurostat (2002): "New enterprises and development of enterprises in Central-European countries," Office for Official Publications of the European Communities, Luxembourg.

Friedman, Milton (1962): "Capitalism \& freedom," The University of Chicago Press, Chicago.

Gale, William (1999): "Why are taxes so complicated," The Brookings Review, Winter 1999, pp. 36-39.

Gemmell, N., O. Morrissey \& A. Piznar (1999): "Do British voters perceive taxes accurately?," mimeo, University of Nottingham.

Gwartney, James \& Robert Lawson with Walter Park, Smita Wagh, Chris Edwards, and Veronique de Rugy (2002): "Economic freedom of the world: 2002 annual report," The Fraser Institute, Vancouver, B.C. Data retrieved from www.freetheworld.com

Gwartney, James, Robert Lawson \& Randall Holcombe (1998): "The size and functions of government and economic growth," prepared for the Joint Economic Committee (Jim Saxton (R-NJ), Chairman), Washington, D.C.

Gwartney, James, Robert Lawson \& Randall Holcombe (1999): "Economic freedom and the environment for economic growth," Journal of Institutional and Theoretical Economics, vol. 155, no. 4, pp. 643-663. 
Haan, Jacob de \& Jan-Egbert Sturm (1999): "On the relationship between economic freedom and economic growth," European Journal of Political Economy, 16, pp. 215-241.

Hansen, Henrik \& Finn Tarp (2001): "Aid and growth regressions," Journal of Development Economics, vol. 64, pp. 547-570.

Hansson, Pär \& Magnus Henrekson (1994): "A new framework for testing the effect of government spending on growth and productivity," Public Choice, no. 81, pp. 381401.

Havrylyshyn, Oleh (2001): "Recovery and growth in transition: a decade of evidence," IMF Staff Papers, vol. 48, Special Issue, pp. 53-87.

Heckelman, Jac C. \& Michael D. Stroup (2000): "Which economic freedoms contribute to growth?," Kyklos, vol. 53, fasc. 4, pp. 527-544.

Heckelman, Jac C. (2000): "Economic freedom and economic growth: a short-run causal investigation," Journal of Applied Economics, vol. III, no. 1, pp. 71-91.

Henderson, Jason (2002): "Building the rural economy with high-growth entrepreneurs," Federal Reserve Bank of Kansas City Economic Review, v87, n3, pp. 45-70.

Henrekson, M. (1988): "Swedish government growth: a disequilibrium analysis," in Henrekson, M. \& J.A. Lybeck (Eds.): "Explaining the growth of government," North Holland, Amsterdam.

Hettich, Walter \& Stanley L. Winer (1988): "Economic and political foundations of tax structure," American Economic Review, vol. 78, no. 4, pp. 701-712.

Heyndels, B. \& C. Smolders (1995): "Tax complexity and fiscal illusion," Public Choice, no. 85 , pp. $127-141$.

Holzman, Franklyn D. (1950): "Commodity and income taxation in the Soviet Union," Journal of Political Economy, vol. 58, issue 5, pp. 425-433.

Hyman, David (1996): "Public finance - a contemporary application of theory to policy," Fifth edition, The Dryden Press, Fort Worth.

IMF (1997): "Government finance statistics yearbook 1997," International Monetary Fund, Washington, D.C.

Kirzner, Isreal M. (1997): "Entrepreneurial discovery and the competitive market process: an Austrian approach," Journal of Economic Literature, v35, n1, pp. 60-85. 
Kornai, Janos (1992): "The socialist system - the political economy of Communism," Princeton University Press, Princeton, N.J.

Kreft, Steven F. \& Russell S. Sobel (2003): "Public policy, entrepreneurship, and economic growth," West Virginia University Economics Working Papers 02-2003, Morgantown, WV.

Leibenstein, Harvey (1968): "Entrepreneurship and development," American Economic Review, Papers and proceedings of the eightieth annual meeting of the American Economic Association, vol. 58, issue 2, pp. 72-83.

Levine, Ross \& David Renelt (1992): "A sensitivity analysis of cross-country growth regressions," American Economic Review, vol. 82, no. 4, pp. 942-963.

McMillan, John \& Christopher Woodruff (2002): The central role of entrepreneurs in transition economies," Journal of Economic Perspectives, vol. 16, no. 3, pp. 153-170.

Meltzer, Allan H. \& Scott F. Richard (1983): “Tests of a rational theory of the size of government," Public Choice, vol. 41, pp. 403-418.

Milanovic, Branko (1999): "True world income distribution, 1988 and 1993. First calculation based on household surveys alone," The World Bank, Washington, D.C.

Minniti, Maria (1999): "Entrepreneurial activity and economic growth," Global Business and Economics Review, v1, n1, pp. 31-42.

Misiolek, W. S. \& H. W. Elder (1988): "Tax structure and the size of government: an empirical analysis of the fiscal illusion and fiscal stress arguments," Public Choice, no. 57 , pp. 233-245.

Mueller, Dennis C. (1989): “Public choice II," Cambridge University Press, Cambridge.

Munley, Vincent G. \& Kenneth V. Greene (1978): "Fiscal illusion, the nature of public goods and equation specification," Public Choice, vol. 33, no. 1, pp. 95-100.

Niskanen, William (1968) “ The peculiar economics of bureaucracy," American Economic Review, vol. 58, issue 2, papers and proceedings of the eightieth annual meeting of the American Economic Association, pp. 293-305.

North, Douglass C. (1990): "Institutions, institutional change and economic performance," Cambridge University Press, Cambridge, UK.

Oates, Wallace E. (1988): On the nature and measurement of fiscal illusion: a survey," in Geoffrey Brennan et al (Eds.): "Taxation and fiscal federalism: essays in honour of Russell Matthews," Australian National Press, Sydney. 
O'Driscoll, Jr., Gerald P., Edwin J. Feulner \& Mary Anastasia O'Grady, with Ana I. Eiras and Brett D. Schaefer: (2003): "2003 index of economic freedom," The Heritage Foundation and The Wall Street Journal, Washington D.C. and New York.

OECD (1998): "Fostering entrepreneurship," Organization for Economic Co-operation and Development, Paris.

OECD (2001): "Internationa development statistics 2001," Organization for Economic Cooperation and Development, Paris

OECD (2000): "Revenue statistics 2000," Organization for Economic Co-operation and Development, Paris.

Olson, Mancur, Jr. (1965): "The logic of collective action," Harvard University Press, Cambridge.

Olson, Mancur, Jr. (1982): "The rise and decline of nations: economic growth, stagflation and social rigidities," Yale University Press, New Haven.

Olson, Mancur, Jr. (1996): "Big bills left on the sidewalk: why some nations are rich, and others poor," Journal of Economic Perspectives, vol. 10, issue 2, pp. 3-24.

Olson, Mancur, Jr. (2000): "Power and prosperity: outgrowing Communist and Capitalist dictatorships," Basic Books, New York.

Ovaska, Tomi \& Russell S. Sobel (2003): "Entrepreneurship in post-socialist economies," mimeo, West Virginia University, Morgantown WV.

Pfirman, Oliver \& Günter H. Walter (Eds.) (2002): "Small firms and entrepreneurship in Central and Eastern Europe," Technology, Innovation and Policy Series 14, Frauenhofer Institute for systems and innovation research, Physica-Verlag, Heidelberg.

Pommerehne, W. W. \& F. Schneider (1978): "Fiscal illusion, political institutions, and local spending," Kyklos, vol. 31, no. 3, pp. 381-408.

Porter, Michael E, Jeffrey D. Sachs, Peter K. Cornelius, John W. McArthur \& Klaus Schwab (2002): "The global competitiveness report 2001-2002," Oxford University Press, New York.

Puviani, Amilcare (1903): "Teoria della Illusione Finanziaria," Palermo.

Rand, Ayn (1964): “The virtue of selfishness," Signet Books, New York.

Reynolds, Paul D.; Michael Hay \& S. Michael Camp (1999): "Global entrepreneurship monitor, "Kauffman Center for Entrepreneurial Leadership, Kansas City, Missouri. 
Schumpeter, Joseph (1934): "The theory of economic development," Harvard University Press, Cambridge, MA.

Schumpeter, Joseph (1942): "Capitalism, socialism, and democracy," Harper, New York.

Shearman, Thomas G. (1891): "Crooked taxation," Publications of the American Economic Association, vol. 6, issue 1/2, pp. 88-95.

Tyran, Jean-Robert \& Rupert Sausgruber (2000): "On fiscal illusion," mimeo, University of St. Gallen.

Vasquez, Ian (1998): "Official assistance, economic freedom, and policy change: is foreign aid like champagne?," Cato Journal, vol. 18, no. 2, pp. 275-286.

Wagner, Richard E. (1976): "Revenue structure, fiscal illusion, and budgetary choice," Public Choice, vol. 25, no. 4, pp. 45-61.

Weingast, Barry R., Kenneth A. Shepsle \& Christopher Johnsen (1981): "The political economy of benefits and costs: a neoclassical approach to distributive politics," Journal of Political Economy, vol. 89, no. 4, pp. 642-664.

Wicksell, Knut [1896](1958): "A new principle of just taxation," in R.A. Musgrave and A.T. Peacock (eds.): "Classics in the theory of public finance," pp. 73-118.

Widmalm, Frida (2001): "Tax structure and growth: are some taxes better than others," Public Choice, no. 107, pp. 199-219.

The World Bank (1998): “Assessing aid: what works, what doesn't, and why," Oxford University Press, Oxford.

The World Bank (2001, 2002): "World Development Indicators," Washington, DC.

Wu, Wenbo \& Otto A. Davis (1999): "The two freedoms, economic growth and development: an empirical study," Public Choice, 100, pp. 39-64.

Zacharakis, Andrew L., William D. Bygrave \& Dean A. Shepherd (2000): "Global Entrepreneurship Monitor: National Entrepreneurship Assessment: United States of America," Kauffman Center for Entrepreneurial Leadership, Kansas City, Missouri. 